\title{
Cigarette Smoke Particle-Induced Lung Injury and Iron Homeostasis
}

\author{
Andrew J Ghio' \\ Elizabeth N Pavlisko ${ }^{2}$ \\ Victor L Roggli ${ }^{2}$ \\ Nevins W Todd ${ }^{3}$ \\ Rahul G Sangani ${ }^{4}$ \\ 'Human Studies Facility, US \\ Environmental Protection Agency, Chapel \\ Hill, NC, 275I4, USA; ${ }^{2}$ Department of \\ Pathology, Duke University, Durham, \\ NC, USA; ${ }^{3}$ Department of Medicine, \\ University of Maryland, Baltimore, MD, \\ 2I20I, USA; ${ }^{4}$ Department of Medicine, \\ West Virginia University, Morgantown, \\ WV, USA
}

Correspondence: Andrew J Ghio Human Studies Facility, US Environmental Protection Agency, 104 Mason Farm Road, Chapel Hill, NC, USA

Email ghio.andy@epa.gov

\begin{abstract}
It is proposed that the mechanistic basis for non-neoplastic lung injury with cigarette smoking is a disruption of iron homeostasis in cells after exposure to cigarette smoke particle (CSP). Following the complexation and sequestration of intracellular iron by CSP, the host response (eg, inflammation, mucus production, and fibrosis) attempts to reverse a functional metal deficiency. Clinical manifestations of this response can present as respiratory bronchiolitis, desquamative interstitial pneumonitis, pulmonary Langerhans' cell histiocytosis, asthma, pulmonary hypertension, chronic bronchitis, and pulmonary fibrosis. If the response is unsuccessful, the functional deficiency of iron progresses to irreversible cell death evident in emphysema and bronchiectasis. The subsequent clinical and pathological presentation is a continuum of lung injuries, which overlap and coexist with one another. Designating these non-neoplastic lung injuries after smoking as distinct disease processes fails to recognize shared relationships to each other and ultimately to CSP, as well as the common mechanistic pathway (ie, disruption of iron homeostasis).
\end{abstract}

Keywords: iron, ferritins, pulmonary disease, chronic obstructive, pulmonary emphysema, chronic bronchitis, hypertension, pulmonary, pulmonary fibrosis

\section{Introduction}

Cigarette smoking is associated with non-neoplastic lung injuries including bronchiolitis/pneumonitis, asthma, pulmonary hypertension, chronic bronchitis, pulmonary fibrosis, emphysema, bronchiectasis, and chronic obstructive pulmonary disease (COPD). The mechanistic pathway by which cigarette smoking initiates these injuries remains to be defined. It is proposed that the basis for non-neoplastic lung injuries associated with smoking is disruption of iron homeostasis in cells after exposure to cigarette smoke particle (CSP) (Figure 1). Following the complexation of intracellular iron by the CSP, inflammation, mucus production, and fibrosis attempt to reverse a functional metal deficiency. If the deficiency in cell iron is not corrected, the response progresses to include injuries associated with irreversible cell death including emphysema and bronchiectasis.

Clinical presentations and pathological observations of non-neoplastic injuries among smokers frequently do not fit into what has been previously described as a single disease entity or diagnosis but demonstrate shared features. This reflects 1) temporal disparities with the patient serially exposing lung tissue to CSP over decades, 2) differences in the deposition and retention of particle which is heterogeneous, and 3) progression of injury. Accordingly, smoking-related injury consists of sequelae to particle exposure that overlap and coexist with one another (eg, 


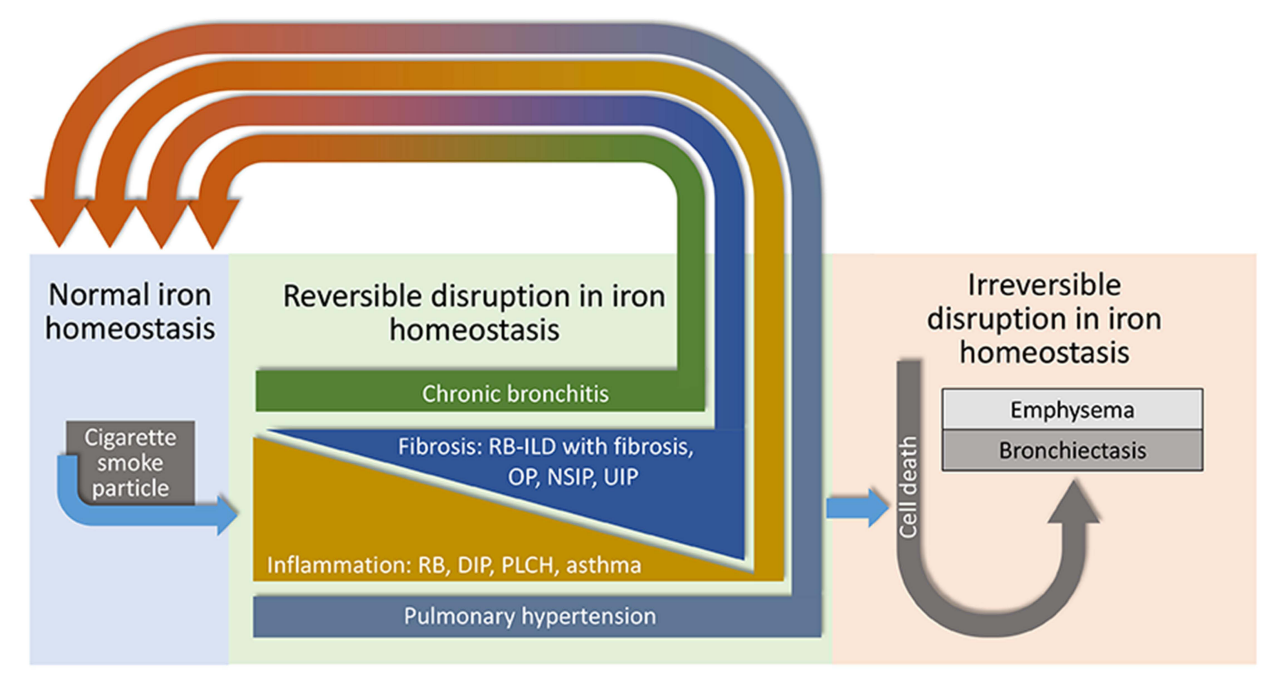

Figure I Schematic depicting the mechanistic basis for non-malignant lung injuries with smoking. CSP disrupts cell iron homeostasis by complexation and sequestration of intracellular metal. Host responses of inflammation, mucus production, and fibrosis attempt to reverse inadequate cell iron concentrations. Without correction, the deficiency in cell iron leads to irreversible cell death evident in emphysema and bronchiectasis. RB, respiratory bronchiolitis; DIP, desquamative interstitial pneumonitis; PLCH, pulmonary Langerhans' cell histiocytosis; RBILD, respiratory bronchiolitis with interstitial lung disease; OP, organizing pneumonitis; NSIP, non-specific interstitial pneumonitis; UIP, usual interstitial pneumonitis.

asthma-COPD and combined pulmonary fibrosis and emphysema syndromes) (Figure 2).

\section{Smoking and Iron Homeostasis}

During smoking, a lack of oxygen and an incomplete incineration of tobacco result in the generation of a complex aerosol, which includes condensed liquid droplets (the particulate fraction or tar) suspended in a mixture of volatile/semi-volatile compounds and combustion gases (the gas fraction). Smoking one cigarette exposes the human respiratory tract to a remarkable mass of particulate matter (PM), between 15,000 and 40,000

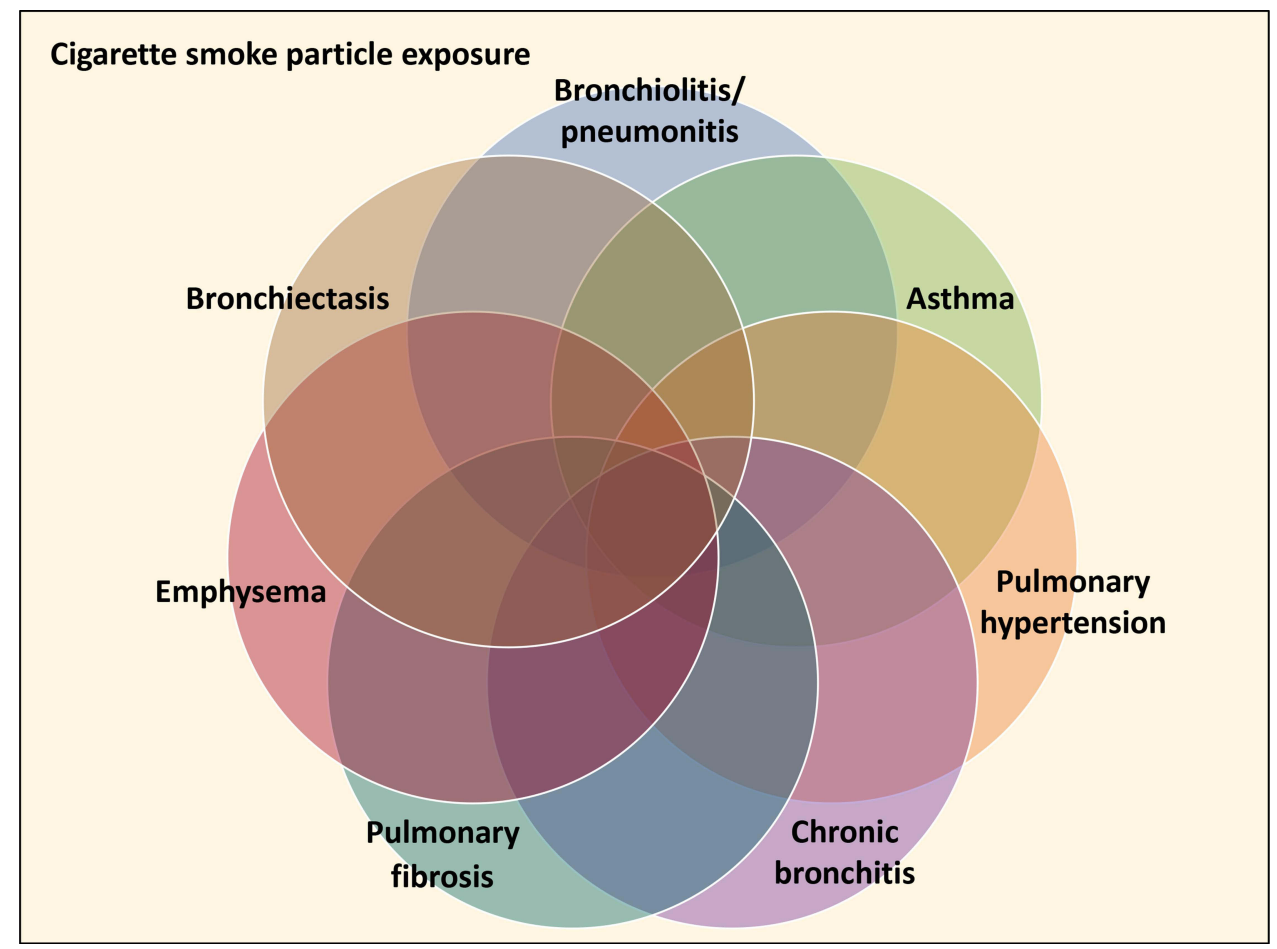

Figure 2 Venn diagram of potential non-malignant lung injuries after cigarette smoking. Presentations with overlap between two or more lung injuries are numerous. 
$\mu \mathrm{g} .{ }^{1}$ The deposition fraction of CSP (with a mean diameter of about $0.2-0.5 \mu \mathrm{m}$ ) in the lung is projected to be 70 $90 \%$ with the greatest of this occurring in the 16 th to 19 th generations of airways (which includes the respiratory bronchioles). ${ }^{2-5}$ There is a gravitational gradient in the ventilation distribution with dependent regions receiving more of each breath than the non-dependent regions and particle deposition is subsequently highest in the lower lung lobes. ${ }^{6}$ Soluble components of CSP can be transported to the blood. ${ }^{2}$ Clearance of the insoluble components of the particle is to the gastrointestinal tract and lymph nodes and slowest from the alveolar region where it is dependent on macrophage function. ${ }^{7,8}$ Accordingly, the lungs of cigarette smokers reveal enormous numbers of both intracellular and extracellular particles, with the former most frequently being in macrophages (Figure 3). Particle is observed to fill macrophages in small airways and alveolar regions in the inflammatory response. In the alveolar regions, pigment-laden cells may no longer be evident, but the accumulated particle remains intact with clusters of anthracotic material being discernable and the size of the individual aggregates of particle and the spatial relationships between them approximate those in the cellular collections.
Cells exposed to tobacco smoke become laden with a material that is variably described to be orange, red, brown, or black in color and fluorescent. This appearance is consistent with humic-like substances (HULIS) which are complex, organic, macromolecular compounds that comprise approximately $7-10 \%$ (mass/mass) of CSP. ${ }^{9-18}$ As a result of having a variety of oxygen-containing functional groups (mostly phenols and carboxylates), HULIS reacts with metal cations to form coordination complexes and, among these, iron is kinetically the most favored. ${ }^{19-22}$ Subsequently, cell exposure to CSP, with its included HULIS, results in an internalization and successive complexation and sequestration of host iron at the particle surface. ${ }^{12,23-29}$ Compounds which complex iron can provide a template for additional condensation of ironhydroxides and a formation of oxide-centered nanoparticles follows. ${ }^{30}$ Iron homeostasis in the cell is disrupted. Macrophages laden with iron (ie, sideromacrophages) are observed with smoking and provide direct support for the capacity of CSP to disrupt iron homeostasis and accumulate metal in exposed cells (Figure 4). ${ }^{16,31-33}$ Quantities of this specific metal in macrophages increase proportionally to the frequency and duration of cigarette smoking. ${ }^{25,28,34}$

A unique coordination chemistry led to the evolutionary selection of iron for a wide range of fundamental cell
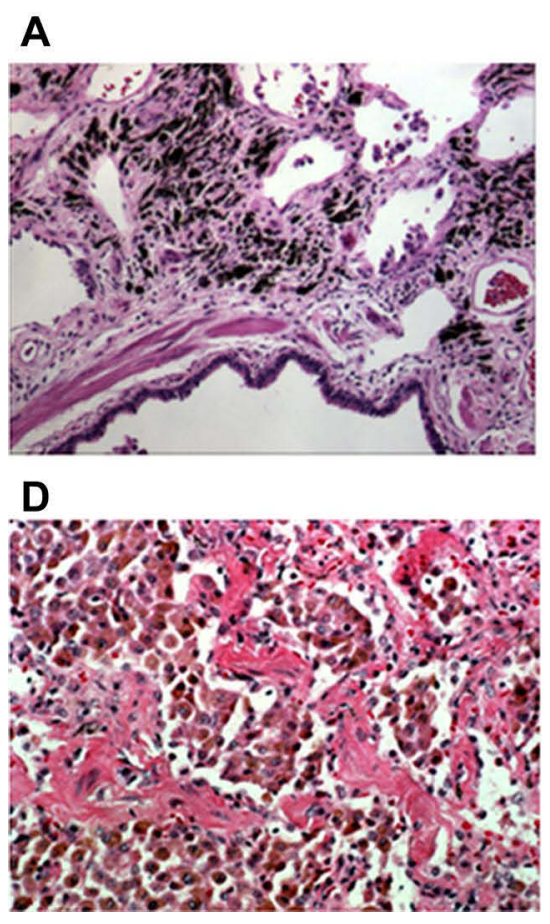

B

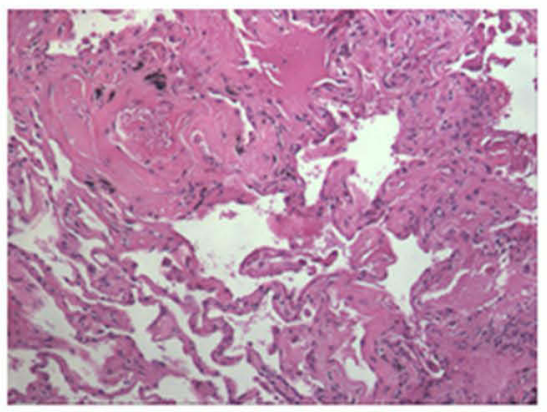

E

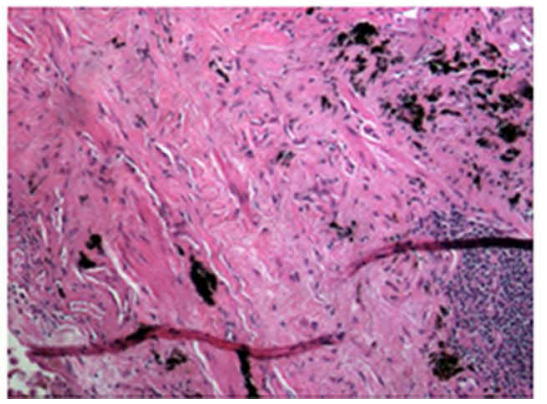

C

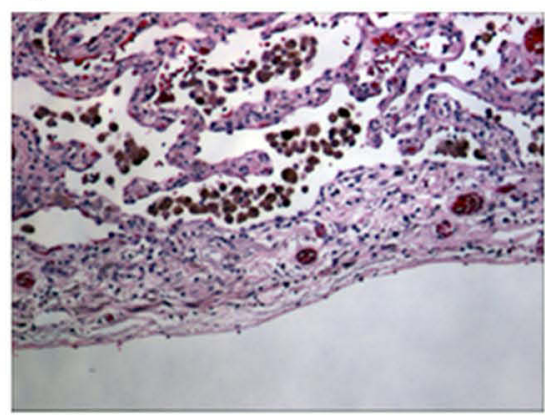

$\mathbf{F}$

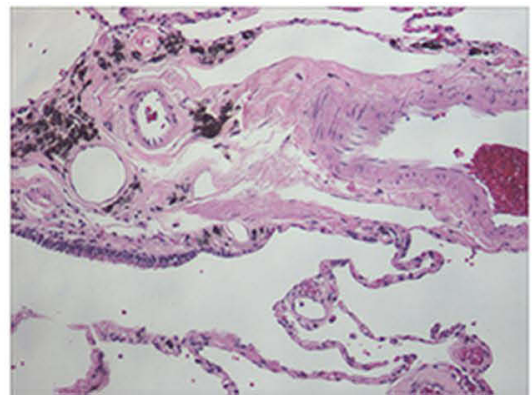

Figure 3 CSP in the human lung. Smokers show particle in close proximity to both airways (A) and vascular structures (B) and intracellularly within macrophages in distant sub-pleural regions (C). CSP is evident in lung resected from patients with inflammatory lung injury (D), fibrosis (E), and emphysema (F). Stain is hematoxylin and eosin. Magnification approximates $100 \times$. 

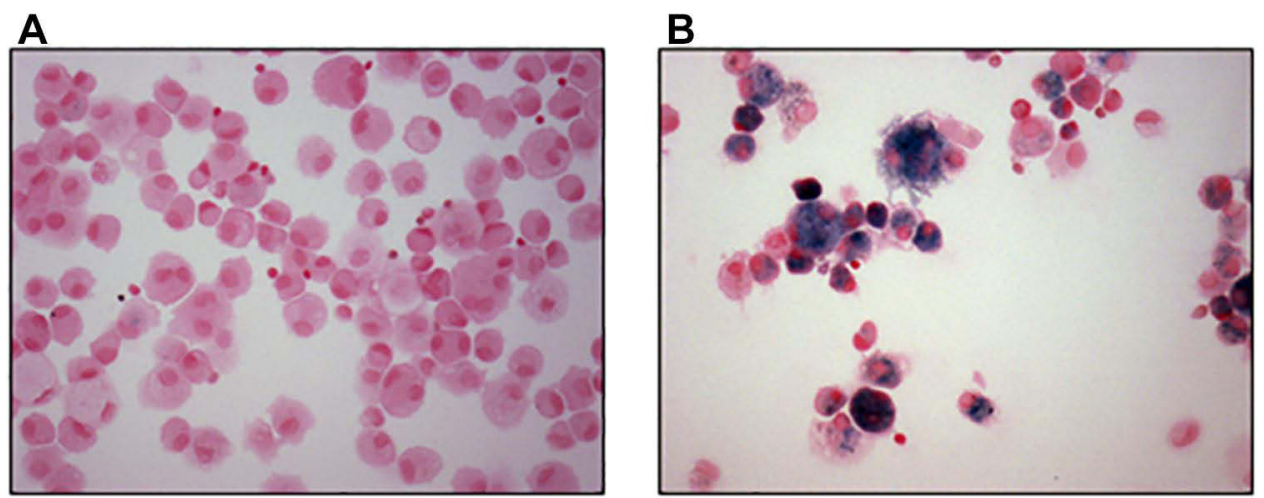

Figure 4 Siderophages in macrophages collected by bronchoalveolar lavage. Macrophages collected from nonsmoker (A) do not stain for iron (blue) while those from a smoker (B) do. Stain is Perls' Prussian blue. Magnification approximates 400x.

functions and its availability is essential for almost every form of life. ${ }^{35}$ A lack of available iron can restrict life in environments ranging in size from the ecosystem of the Pacific Ocean to a bacterium. ${ }^{36,37}$ Iron concentrations inadequate to meet the requirements for life necessitate a development of pathways to acquire the critical metal. Concurrently, a metal-catalyzed generation of radicals presents a potential for oxidative stress. Therefore, iron homeostasis, including its import, storage, and export, are vigilantly regulated and life exists at the interface between iron-deficiency and -sufficiency. After the cell reaches some lower threshold of iron concentration, there is an obstruction of the cell cycle and an initiation of regulated cell death. ${ }^{38-40}$

Intracellular iron levels immediately available for complexation in lung cells exposed to CSP are very low approaching the concentration of the labile iron pool (less than $1-5 \mu \mathrm{M}){ }^{41,42}$ Accordingly, CSP competes for iron utilized by the cell for functions frequently critical for survival (Figure 5). With metal accumulation by the particle surface following its complexation, the cells exposed to CSP must appreciate a functional iron deficiency. While the total iron is either the same or increased, the concentration of metal in the cells exposed to CSP will be

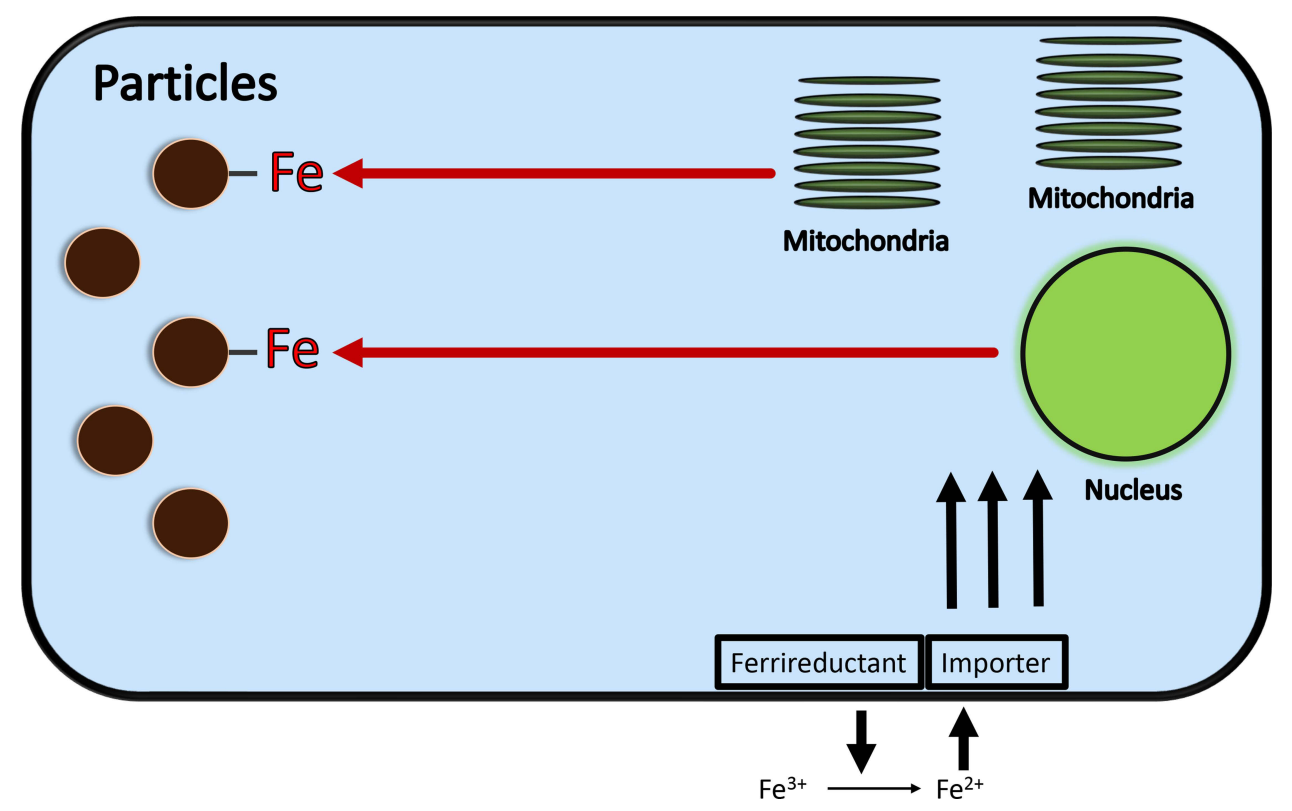

Figure 5 Schematic for changes in iron homeostasis following CSP exposure. Functional groups at the surface of the CSP, including HULIS, complex and sequester iron from the cell. A functional metal deficiency results. In response to a reduction in intracellular iron, the cell upregulates iron import in an attempt to reacquire requisite metal. If the cell response to increase metal is inadequate, function and survival are compromised. 
insufficient to meet the requirements for function as a result of its sequestration by the particle. The cell subsequently increases import of iron and, if successful, cell concentrations rise and metal levels will be sufficient to meet requirements for continued function despite the complexation of host resources by internalized CSP. However, if either enough host iron is complexed by the particle or the cell response to increase metal is inadequate, function and survival are compromised and cell death is predicted.

Investigation employing bronchoalveolar lavage supports both increased and decreased iron concentrations in the epithelial lining fluid of smokers and will be dependent on whether the individual is actively smoking. ${ }^{27,43,44}$ Exhaled breath condensate (EBC) is an alternative approach to sampling the epithelial lining fluid and has demonstrated decreased iron concentrations among patients diagnosed with smoking-related lung disease (eg, COPD). ${ }^{44-46}$ After complexation of iron by the CSP affecting a functional iron-deficiency, the cell will attempt to reverse the loss of requisite iron and this will include expression of proteins involved in metal import (eg, transferrin receptor and DMT1). ${ }^{47-49}$ Compared to nonsmokers' lungs, both transferrin and transferrin receptor expression in cells and fluids can be higher relative to those with smoking-related disease. Iron is imported into a cell only after ferrireduction (eg, superoxide generation) and this must similarly increase with exposure to $\mathrm{CSP}^{50}$ In an animal model exposed to cigarette smoke, increases in lavage concentrations of iron and ferritin, and nonheme iron concentrations in the lung are reversed after filtering to remove particles. ${ }^{23}$ Exposure of respiratory epithelial cells to CSP (and its components) affects an increased import and accumulation of iron. ${ }^{14,23}$ These findings support complexation of cell iron by CSP and a cellular response to a functional metal deficiency in the lungs of smokers and/or those with disease after smoking. ${ }^{51}$

Iron homeostasis is also altered systemically with smoking. Reflecting a diminished availability of metal after smoking, iron deficiency is common in smoking populations. ${ }^{52-54}$ Anemia is more frequently observed in both smokers and populations with smoking-related disease with a prevalence in COPD that varies between $4.9 \%$ and $44 \% .^{52,55-58}$ The two primary types of anemia seen in smoking-related disease are anemia of chronic disease and iron-deficiency anemia; both are related to alterations in iron homeostasis.

\section{Bronchiolitis/Pneumonitis}

Respiratory bronchiolitis (RB) is a universal inflammatory reaction that occurs in smokers (ie, smoker's bronchiolitis). ${ }^{59,60}$ It is characterized histologically by a patchy accumulation of pigmented smoker's macrophages, consistent with an accrual of HULIS, in the respiratory bronchioles (ie, that region with the greatest CSP deposition). ${ }^{61,62} \mathrm{RB}$ is most frequently noted as an incidental histologic abnormality and few patients are symptomatic. With continued exposure, greater particle deposition will occur in the alveolar region where it will initiate an inflammatory response consistent with desquamative interstitial pneumonitis (DIP) which is characterized by numerous pigmented macrophages, and sometimes giant cells, within the distal airspace of the lung (Figure 3D). ${ }^{63,64}$ The prevalence and incidence of DIP are unknown, but an association with cigarette smoke has been demonstrated and the majority of patients are smokers. ${ }^{65}$ While the feature that differentiates RB from DIP is most frequently cited as the distribution and extent of macrophage accumulation (that is bronchiolocentric in RB and more diffuse in DIP), there are no reliable histologic features to distinguish the two inflammatory responses with certainty and they can be considered different phases of a single response. ${ }^{60,66}$ Smoking cessation is currently considered the primary treatment for both RB and DIP and survival rates are favorable. This inflammatory response can persist in patients after smoking cessation supporting particle participation as CSP remains in the lung for years. ${ }^{67,68}$

Pulmonary Langerhans' cell histiocytosis (PLCH) is characterized by the proliferation of specialized dendritic cells, known as Langerhans' cells, that form multiple, bilateral, stellate-shaped nodules, which frequently cavitate. ${ }^{69,70}$ These peribronchiolar lesions are often associated with smokers' pigmented macrophages as well as an influx of eosinophils and lymphocytes in the distal bronchioles. $^{61,70}$ The incidence of PLCH is unknown and is difficult to determine since it is frequently asymptomatic and can resolve spontaneously. PLCH most frequently occurs in young adults with a peak incidence at 20-40 years of age, and almost all patients are either current or previous cigarette smokers. With smoking, a mixture of respiratory bronchiolitis, DIP, and $\mathrm{PLCH}$ is commonly observed histologically and their differentiation from one another can be difficult. ${ }^{66}$ Since the CSP deposition is greatest at the respiratory bronchiole, RB is the earliest 
inflammatory injury observed after smoking and temporally this can be followed by DIP and PLCH as the exposure increases with continued smoking.

The focus of the inflammatory response after smoking is suggested to be a reacquisition by the host of its iron sequestered by CSP. This is equivalent to inflammation following exposures to microbes, which reduces infection to a "battle for iron". ${ }^{36}$ By impacting a functional iron deficiency in the host, CSP exposure initiates inflammation similar to other particles. ${ }^{71-84}$ This response includes increased oxidative stress, cell signaling, transcription factor activation, and release of mediators. ${ }^{83-91}$ Cell exposures to compounds and substances with a capacity to complex iron, including CSP and other particles, correlate with increased oxidant generation. ${ }^{92-95}$ Such oxidants, specifically superoxide and its related products, can follow a loss of requisite iron from the cell to a particle. ${ }^{79}$ At the level of a living system, the provision of an iron-deficient diet results in an anemia and an increase in oxidant generation. ${ }^{96}$ Superoxide, produced by the cell in response to metal deficiency, enables the import of requisite iron through the chemical reduction of $\mathrm{Fe}^{3+}$ to $\mathrm{Fe}^{2+}$. This ferrireduction is an essential, and frequently limiting, reaction in iron import. ${ }^{97-99}$ Cellular iron deficiency and its associated oxidative stress influence numerous pathways which coordinate an inflammatory response including an activation of specific kinases (eg, p38, JNK, ERK1, and ERK2) ${ }^{87,88,100-105}$ Phosphorylation of kinases following exposure to inflammatory agents, including particles, can be decreased by augmenting the cell concentration of available iron supporting a role in metal homeostasis. ${ }^{79}$ Comparable to kinase activation, diminished cell iron concentration corresponds to an activation of specific proinflammatory transcription factors also favoring a participation in metal homeostasis (eg, NF- $\mathrm{B}$, AP-1, HIF- $\alpha$, CREB, and NRF). ${ }^{87,88,101,103,106-116}$ Finally, inflammatory mediator release increases with a decreased availability of iron. ${ }^{83,85,100,101,107,113,115,117,118}$ Cigarette smoking demonstrates a dose-dependent association with increased concentrations of inflammatory cytokines and cells in the lower respiratory tract. ${ }^{119}$ This association of the release of pro-inflammatory cytokines with a disruption in iron homeostasis has been demonstrated after exposure to CSP. ${ }^{14,81,120-122}$ This coordinated inflammatory response to CSP is comparable to activation of pathways observed with metal deficiency following cell exposures to other compounds and substances with a similar capacity to complex iron. ${ }^{83,85,89}$ Even with cessation of smoking, the HULIS in the retained particle will continue to complex available host iron as long as it persists in the lower respiratory tract therefore impacting a functional metal deficiency and initiating the inflammatory response (eg, RB and DIP).

\section{Asthma}

There are numerous associations between asthma, an inflammatory airways injury, and smoking. ${ }^{123,124}$ Both current and former smokers are at increased risk of developing asthma., ${ }^{5,125-127}$ Smoking also increases exacerbations, severity, hospitalizations, and mortality of asthma. $^{5,125,127-131}$ Asthma associated with smoking demonstrates poorer control, impaired response to corticosteroid therapy, accelerated decline in lung function, and increased rate of healthcare utilization. ${ }^{123,124,128}$ There is a comparable causal relationship between exposure to environmental tobacco smoke (ETS) and asthma in nonsmoking adults and children. ${ }^{126,132-138}$ Evidence also supports an association between ETS exposure and asthma exacerbation. ${ }^{132}$ Bronchial hyperresponsiveness (BHR) is regarded as a hallmark feature of asthma and bronchoprovocation testing is performed to support its diagnosis. ${ }^{139}$ Both cigarette smoking and ETS increase BHR. ${ }^{140-146}$ Finally, there is an interaction between maternal smoking and asthma with increasing risk for physician-diagnosed asthma in the newborn and during both childhood and adolescence. $^{136,147-151}$

The mechanism by which exposure to cigarette smoke causes these effects is not established but asthma can be associated with a deficiency of iron (both functional and absolute) initiated by particle exposure. ${ }^{152}$ While the largest quantity of CSP can be observed in the distal alveolar regions with smoking, the highest particle mass per epithelial surface area can be in the proximal conducting airways, due to smaller surface areas. ${ }^{9}$ Accordingly, an associated functional iron deficiency by the CSP and initiation of oxidative stress, activation of cell signaling and transcription factors, and release of proinflammatory mediators can result in an airways inflammation recognized clinically as asthma. In support of this, the inhalation of an iron chelator (ie, citric acid) increases BHR and causes bronchoconstriction. ${ }^{153,154}$ In addition, particlerelated exposures other than cigarette smoking, which similarly complex metal and disrupt iron homeostasis, elevate BHR in a dose-dependent manner. ${ }^{145,155-157}$ Regarding maternal smoking and asthma in the newborn, iron is accumulated by the developing fetus against 
a concentration gradient and many stresses will impact the availability of this metal. There are statistically significant negative correlations between maternal smoking and an infants' total body iron. ${ }^{158}$ The number of cigarettes smoked per day by the mother correlates negatively with iron availability in newborn infants. In addition, maternal smoking during pregnancy decreases the concentration of available iron in both umbilical cord blood and placenta. ${ }^{159}$

\section{Pulmonary Hypertension}

Pulmonary hypertension ( $\mathrm{PH})$, an abnormal elevation in the pressures of the pulmonary arterial system, is initially an inflammatory disease. Exposure to cigarette smoke directly impacts pulmonary vascular cells to release an abnormal production of mediators, many proinflammatory, that control vascular cell proliferation, and vasoconstriction/vasodilatation. ${ }^{160-163}$ Pulmonary arterial intimal thickening and vessel narrowing are early changes in smokers' lungs and these correlate with endpoints of other smoking-related lung injury (eg, severity of bronchiolitis and emphysema). ${ }^{164,165}$ Among smokers, there is also an increase in pulmonary vascular resistance due to vasoconstriction and thickening of the walls caused by proliferation of smooth muscle and other cells (ie, remodeling of the pulmonary vasculature).

PH is associated with a disruption in iron homeostasis and decreased metal availability. In patients with smokingrelated lung disease, iron deficiency was associated with an increased systolic pulmonary artery pressure. ${ }^{166}$ Iron in lung tissue, which is complexed by CSP, shows an association with right ventricular systolic pressure among patients with idiopathic pulmonary fibrosis (IPF), a smoking-related lung disease. ${ }^{33} \mathrm{~A}$ high prevalence of iron deficiency is present in patients with idiopathic pulmonary arterial hypertension (IPAH) and metal availability corresponded to hemodynamics, functional class/disease severity, and clinical outcome. ${ }^{167-170}$ Similarly, iron deficiency is found in PH patients (38.25\%) (with the highest prevalence being in connective tissue disease associated $\mathrm{PAH}$ ) and is associated with worsened clinical outcome. ${ }^{171,172}$ The effect of hypoxia on pulmonary arterial pressure can depend on the iron status possibly acting through the transcription factor hypoxia-inducible factor. ${ }^{173,174}$ Extrapolating from chronic left heart failure where iron deficiency is recognized to be common and parenteral iron can change exercise capacity and functional class, treatment of metal deficiency can improve
PH. ${ }^{168,169,174,175}$ After administration of intravenous iron, the rise in pulmonary artery pressures with hypoxia can similarly be attenuated. ${ }^{176}$

Regarding a causative relationship of disrupted metal homeostasis with $\mathrm{PH}$, iron is a major participant in pulmonary vascular homeostasis. Intracellular iron deficiency alters pulmonary vascular function and iron-deficient rats can exhibit raised pulmonary artery pressure and right ventricular hypertrophy with profound pulmonary vascular remodeling (eg, prominent muscularization, medial hypertrophy, and perivascular inflammatory cell infiltration). ${ }^{177,178}$ In another animal model, decreased iron availability leads to muscle remodeling, which can be reversed by replacement of the metal. ${ }^{179}$

\section{Chronic Bronchitis}

Chronic bronchitis (CB) is diagnosed in patients with a cough productive of mucus for at least 3 months per year for 2 consecutive years. The primary mechanisms responsible for excessive mucus are overproduction/hypersecretion, by goblet cells and glands, and decreased elimination. Smoking is the primary risk factor for $\mathrm{CB} .{ }^{180}$ The diagnosis of $\mathrm{CB}$ affects outcomes including lung function, exacerbations, hospitalizations, and mortality.

Mucus production in the smoker's airways is proposed as a host response to reverse the functional iron deficiency resulting from metal complexation and sequestration by CSP. Epithelial interfaces exposed to external environments are dominated by linear polysaccharides with large molecular weights. ${ }^{181}$ Among these, glycosaminoglycans (GAGs, also called mucopolysaccharides) are a major component of mucus, produced by either epithelium or glands, and composed of amino sugars and uronic acids (all except for keratin sulfate have glucuronic acid or iduronic acid). ${ }^{182,183}$ These sugar acids contain carboxylate and hydroxyl functional groups, negatively charged molecules, which can participate in cation exchange and metal complexation. ${ }^{184}$ Reflecting this reactivity, hydroxycarboxylates such as GAGs and other sugar acids complex iron and stain with colloidal iron. ${ }^{185-192}$ In this complexation, these polysaccharides employ both carboxylate and hydroxyl groups in the binding of metal. ${ }^{30,193-204}$ Among the metals, complexation of iron is preferred with the stability constant approximating $10^{4} \mathrm{M}^{-1} \cdot{ }^{202-204}$ By acting like organic ligands, these polysaccharides participate in iron homeostasis to enhance bioavailability of metal thus increasing import. ${ }^{205-210}$ Subsequently, production of these polysaccharides can reverse a functional iron 
deficiency. The ability of these polyanionic polysaccharides to complex metals can include bridges between the polymer chains which lead to the formation of ionic crosslinked, supermolecular structures and these can modify the gel polymer networks. ${ }^{211-216}$ Subsequently, with binding of available metal, there is crosslinking, water is expelled, the viscosity of the polysaccharide matrix is altered, chain stiffening follows, and mechanical properties can be changed. ${ }^{217,218}$ Metal cations, including iron, can also depolymerize polysaccharides comparable to other biopolymers. $^{219-223}$ The activity of a lyase can be increased and decreased after exposure to specific metals. ${ }^{224,225}$ With iron deficiency, lyases are activated to produce oligomers (eg, oligogalacturonides) which demonstrate important bioactivities including metal uptake (Figure 6). ${ }^{226,227}$ In contrast to iron deficiency, increased metal availability diminishes this lyase activity. ${ }^{228}$ Accordingly, low iron availability in microbials triggers a coordinated expression of genes encoding lyases with iron transport functions. ${ }^{229,230}$ This synthesis and depolymerization of polysaccharides provides polymeric units with a high number of binding sites utilized for metal import. ${ }^{231}$ This is comparable to several protein polymers which are utilized to increase metal uptake after proteolytic degradation and complexation of the metal by fragments with decreased molecular weight, increased charge with disclosure of reactive functional groups. ${ }^{232}$
In support of a role for these polyanionic polysaccharides in human iron homeostasis, other living systems utilize them to acquire metal. ${ }^{233-235}$ Similar to mucus, capsular polysaccharides in microbes have abundant uronic acid subunits that participate in metal uptake. ${ }^{210,236,237}$ Among the metals, uptake by a capsule is greatest for iron and large concentrations can be detected. ${ }^{210,238}$ Iron availability influences both formation of a capsule and the production of these polysaccharides. ${ }^{239-243}$ Microbials can also generate biofilms, which include polyuronates of varying chain length and composition. ${ }^{196,244}$ With biofilm formation, microbes effectively concentrate and utilize metals with iron being preferred over others. ${ }^{245}$ Microbes respond to iron deficiency by using the metal complexed by the components of the biofilm as a "sink". Removal of iron from a medium increases biofilm and polyuronate production as the microbe attempts to reverse the deficiency. ${ }^{246-248}$ In contrast, elevated iron concentrations inhibit biofilm formation in a dose-dependent manner. ${ }^{249-254}$ Accordingly, biofilm production is induced in iron-restricted conditions and is repressed by increased availability of the metal. ${ }^{249}$ Polyuronates, and mucus production, also participate in iron uptake in plants and animals. ${ }^{229,230}$ A large proportion of metal-binding, required for iron transport in the gastrointestinal tract, is found in goblet cells and the mucin layer located extracellularly in the lumen. ${ }^{231}$ Mucus can be demonstrated to have metal-binding activity using
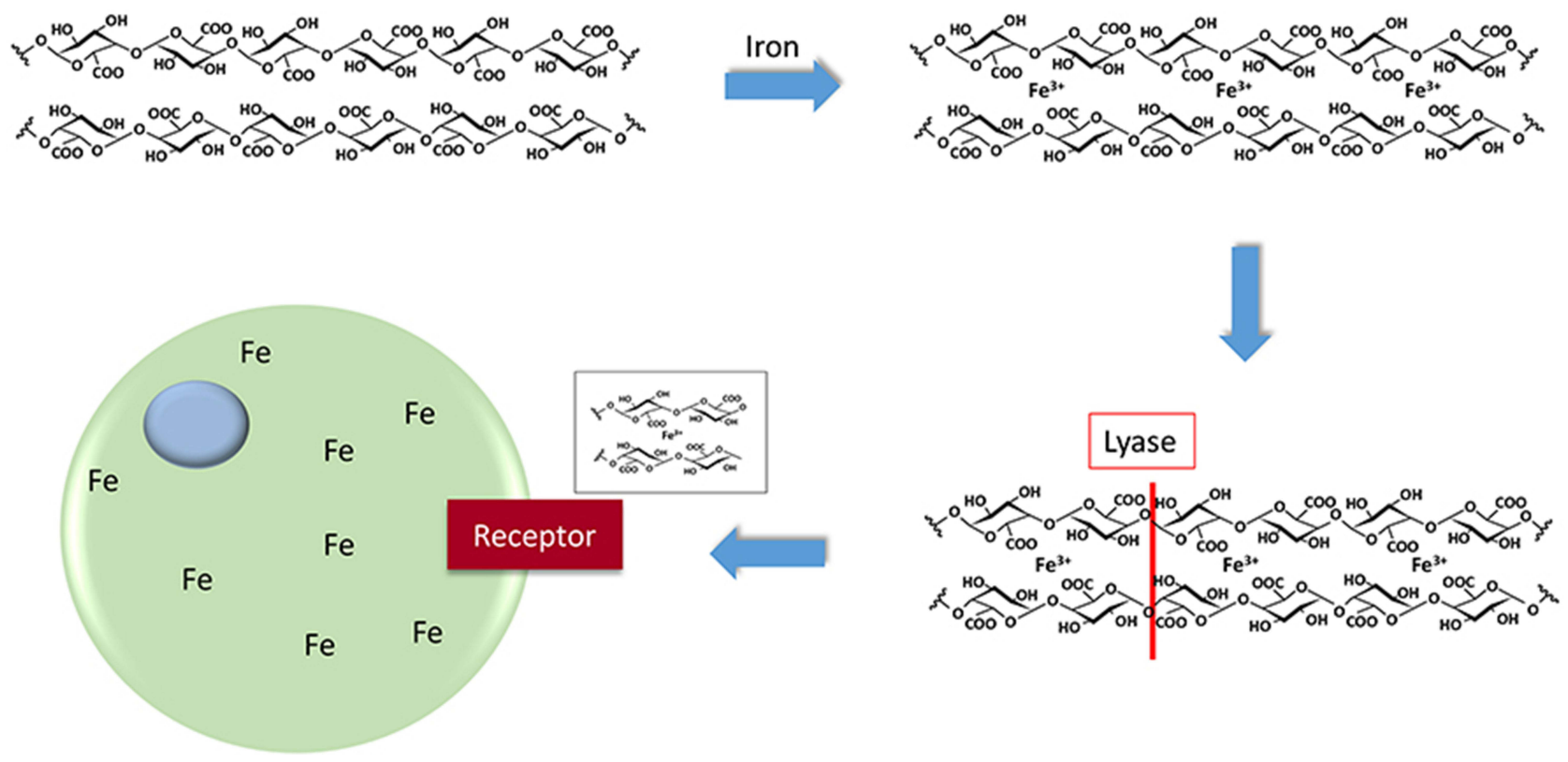

Figure 6 Schematic of iron import by polyanionic polysaccharide. Iron is bound by the polysaccharide using moieties such as carboxylates and hydroxyl groups. Lyase activity, increased by the metal deficiency, provides oligomers with bound iron to the cell for receptor-mediated uptake. 
histologic methodology. ${ }^{190,191,255,256}$ Colloidal iron stains are employed as an assay for in situ iron binding capacity in mucus and confirm metal-binding by carboxylated and sulfated mucopolysaccharides and glycoproteins. ${ }^{257-260}$ Following phagocytosis of mucus, macrophages demonstrate an accumulation of iron. ${ }^{261}$ All this evidence supports an increased mucus production in the smoker's airways as a beneficial host response, which participates in reversing a functional metal deficiency following complexation of iron by CSP. The inclusion of polyanionic polysaccharides (eg, polyuronates) in mucus effectively positions a negative charge on human respiratory cell membranes in the airways which complexes iron. After binding the metal, the polysaccharide is acted on by lyases providing a continual supply of a low molecular iron chelate facilitating import and increasing availability.

\section{Pulmonary Fibrosis}

Evidence supports a relationship between smoking and pulmonary fibrosis. ${ }^{59,262-277}$ This pathobiologic process can be characterized by excessive extracellular matrix (ECM) production, alveolar epithelial cell loss, and alveolar collapse in response to injury. Radiologically, pulmonary fibrosis is recognized by a combination of reticular opacities, volume loss, traction bronchiectasis (dilated, irregularly shaped airways), and honeycombing (clusters of small cysts located in the extreme periphery of the lung), of which the latter two develop as a result of loss in aerated lung volume and permanent alveolar collapse. Pathologically, pulmonary fibrosis manifests as several different histologic patterns: 1) organizing pneumonia (OP), characterized by round or oval pale-staining deposits consisting of fibroblasts, myofibroblasts, collagen, and fibrin within respiratory bronchioles, alveolar ducts and alveoli $^{278}$; 2) nonspecific interstitial pneumonia (NSIP), characterized by inflammation and/or fibrosis in the lung interstitium occurring in a spatially homogeneous pattern and with preservation of overall lung architecture ${ }^{279}$; and 3) usual interstitial pneumonia (UIP), the most severe form of lung fibrosis, characterized by heterogeneous areas of dense fibrosis interspersed with areas of relatively normal lung architecture, fibroblastic foci, and honeycombing. ${ }^{280}$ With the deposition and retention of CSP being greatest in the region of the respiratory bronchioles, an initial fibrosis evolves from the inflammatory response, correlates with the amount smoked, and is observed pathologically as a peribronchiolar fibrosis. ${ }^{4,59,70,281,282}$ With continued smoking (ie, CSP exposure), deposition will extend distally beyond the respiratory bronchiole. OP and NSIP represent earlier phases of the tissue response to CSP while UIP represents a lung response to higher doses and subsequently a later stage. One histologic presentation of injury may progress into the next with overlapping patterns being observed which make strict histopathologic diagnosis difficult or impossible. ${ }^{59,283,284}$ OP components are common lesions in both NSIP and UIP cases, and as fibrosis evolves, pathological areas of NSIP are observed with UIP. ${ }^{285-290}$

Below the resolution of any radiologic imaging, fibrosis can be observed in a majority of smokers. ${ }^{291-293}$ In the last two decades, fibrotic lung injury has presented radiologically without clinical symptoms; studies on large cohorts have reported such interstitial lung abnormalities (ILAs) in $8-20 \%$ of the smokers undergoing high-resolution computed tomography (CT) scanning. ${ }^{267,294-296}$ On pathological examination, ILAs can include both inflammation and fibrosis. ${ }^{297}$ ILAs are a precursor to clinically evident smoking-related fibrotic lung disease.

In support of a role for a metal deficiency participating in lung fibrosis, animal models of fibrotic injury utilize compounds and substances which complex and sequester iron (eg, bleomycin, asbestos, silica, and paraquat). ${ }^{298}$ Reflecting a metal deficiency, 1) iron is lower in breath condensate and 2) gallium uptake, indicating transferrinmediated metal uptake and demand for metal, is increased in the lungs of patients with fibrosis. ${ }^{299-301}$ In patients with particle-related fibrotic lung disease and animal models of lung fibrosis, macrophages demonstrate increased transferrin receptor (CD71) indicating iron insufficiency. ${ }^{302,303}$ A humic substance (fulvic acid), which is chemically analogous to HULIS in CSP, stimulates collagen secretion by articular chondrocytes. ${ }^{304}$ Finally, increased metal availability after treatment with ferric citrate decreases fibrosis in a non-pulmonary tissue of an animal model. ${ }^{305}$

Although pulmonary fibrosis is detrimental to the patient from a lung mechanics and gas exchange standpoint, the fibrotic process may benefit the host response to functional iron deficiency associated with the loss of metal following complexation by $\mathrm{CSP}^{306}$ Fibrotic lung injury associated with smoking is characterized by an excessive accumulation of ECM. Comparable to mucus, polyuronates are a major component of both GAGs and ECM. Hyaluronic acid (HA) is the most abundant GAG in ECM and is increased with smoking. Comparable to other polyuronates, it forms a coordination complex with transition metals including iron. ${ }^{307-309}$ Metals participate in the 


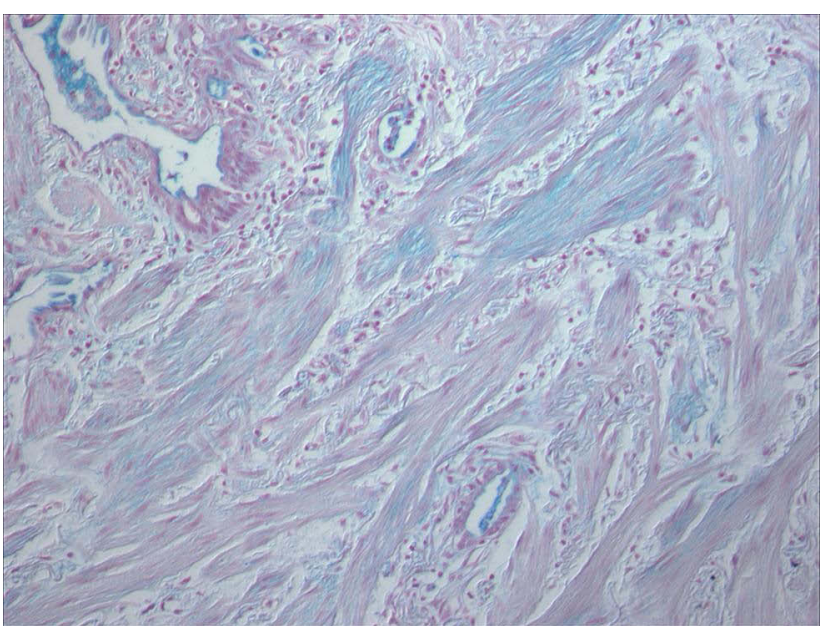

Figure 7 ECM components bind iron. Collagen demonstrates staining for iron (blue) supporting a role for uptake. The stain is colloidal iron. The magnification approximates 100x.

depolymerization and, following the reaction with iron, HA will be degraded..$^{307,310,311}$ Such depolymerization of GAG polysaccharides to oligosaccharides improves cell import of metal. Increased availability of iron inhibits hyaluronidase and degradation products of HA function as mediators of inflammation. ${ }^{312-314}$ The cell receptor for HA is regulated by metal availability and is a major participant in iron uptake. ${ }^{315}$ Collagen is another major component of ECM, being the most abundant protein in mammals, and is also increased in smokers' lungs. ${ }^{268,316-323}$ As a result of abundant functional groups including carboxylates, hydroxyls, and amines, collagen complexes iron which may increase cell availability and possibly reverse a deficiency (Figure 7). ${ }^{324-327}$ Collagen peptides demonstrate iron binding activity. ${ }^{328}$ This interaction of collagen with metals is a recognized method for its stabilization (ie, tanning which most commonly is achieved with chromium but iron cations can be employed). ${ }^{329,330}$ The metal complexed to collagen is considered available to the host and higher doses of iron decrease collagen synthesis further supporting a role in metal homeostasis. ${ }^{331-333}$ Relationships between other components of ECM and iron homeostasis are also evident. $^{268,334-336}$ A Gamma-Gandy body, with dense fibrous tissue and collagenous fibers encrusted with iron and calcium, demonstrates the capacity of ECM to complex metal cations and impact their homeostases. ${ }^{337}$

\section{Emphysema and Bronchiectasis}

Emphysema is characterized by abnormal, permanent enlargement of the airspaces distal to the terminal bronchiole accompanied by destruction of their walls. The early lesion, focal emphysema, involves the branches of the terminal bronchiole, and this is followed by microscopic emphysema with passages of airways affected being the two distal orders of respiratory bronchioles or the first order of alveolar ducts (ie, the site of greatest CSP deposition). Centrilobular emphysema following smoking originates in areas of "parenchymal soot deposits", immediately adjacent to retained particle, and severity is dependent on the total quantity of CSP (Figure 8). ${ }^{23,338-344}$ In these emphysematous foci, there is a brownish-colored pigment noted in both macrophages and interstitium reflecting HULIS in CSP. This relationship between CSP and emphysema suggests particle participation in the destructive process responsible for tissue injury.

Positive stains with Perls' Prussian blue and accumulation of ferritin and hemosiderin demonstrate a disruption of iron homeostasis in emphysema. ${ }^{23,345}$ In mice, provision of an iron-depleted diet was associated with more severe emphysema following cigarette smoke exposure reinforcing the role of the functional metal deficiency in pathogenesis. ${ }^{346}$ When successful in resolving the functional iron deficiency following complexation of host metal to the reactive functional groups at the particle surface, inflammation and fibrosis can reverse. ${ }^{347-352}$ However, with failure to resolve an insufficiency of requisite iron, the cell cycle is obstructed and a form of regulated cell death is initiated. ${ }^{353}$ An increase in apoptotic

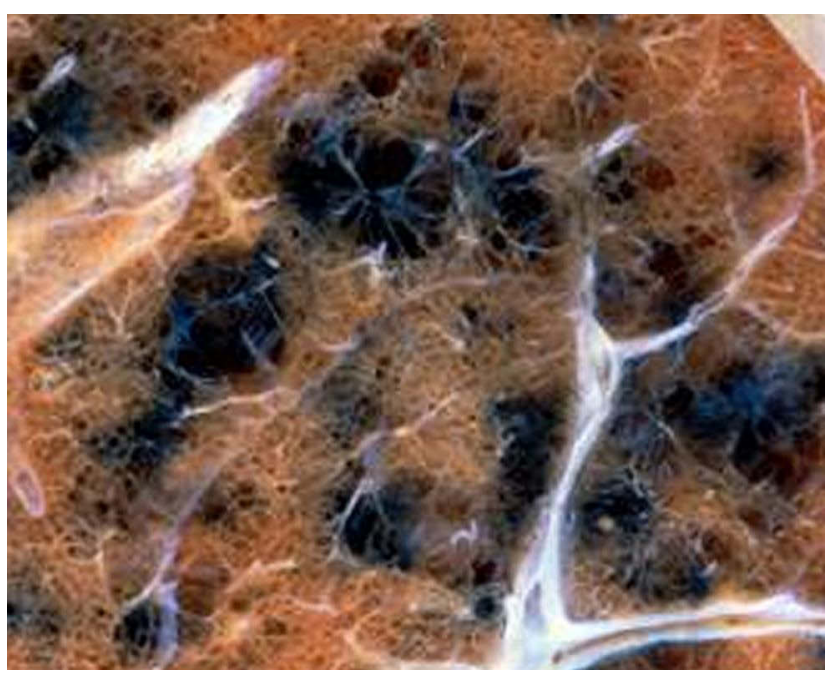

Figure 8 The correlation between CSP and emphysema. Lung tissue of a smoker exhibits a close association between CSP and emphysematous destruction of the parenchyma (ie, bullous formation). The magnification approximates 10x. Adapted with permission of the American Thoracic Society. Copyright (C) 202I American Thoracic Society. All rights reserved. Ghio AJ, Hilborn ED, Stonehuerner JG, et al. Particulate matter in cigarette smoke alters iron homeostasis to produce a biological effect. Am J Respir Crit Care Med. 2008; I78(II):1।30-1 138. ${ }^{23}$ 
cells is observed in the lungs of emphysematous patients. ${ }^{354-370}$ Since this is not counterbalanced by an increase in proliferation, there is a loss of cells resulting in cell/tissue destruction. While mechanisms involved in cell death with emphysema can include a wide range of mediators (eg, oxidative stress, ceramides, vascular endothelial growth factor, and inflammatory cytokines), the critical factor is iron availability. As a result of its central role in complexing the metal and determining availability, cell death will be initiated immediately adjacent to the particle (ie, focal and centrilobular emphysema in the distal bronchiole) as this corresponds to those cells that are functionally iron deficient. Exposure to a substance with this same capacity for metal complexation results in a comparable sequestration of iron, cell death, and contiguous tissue destruction. ${ }^{371,372}$

Bronchiectasis is defined as a permanent enlargement of airways in the lung. It is commonly observed in smoking populations and in IPF patients, with prevalence that can approach 50\% and 95\%, respectively. ${ }^{373}$ The deposition of CSP per unit surface area of a proximal bronchus can be considerably elevated relative to that calculated for the whole lung and airway epithelial cell exposure can be equivalent to or greater than that of alveolar epithelial cells. $^{374}$ Bronchiectasis can result from the disruption of iron homeostasis by CSP in airways with a functional iron deficiency associated with smoking blocking the cell cycle and impacting cell death in airway epithelial cells comparable to that in alveolar epithelial cells observed in emphysema. However, apoptosis in large, tubular structures (eg, bronchi and arteries) produces a pattern of injury, which can include widening and distortion of the cylindrical tissue organization. ${ }^{375-378}$ Accordingly, after some threshold of cell death is realized in the airways, widening (that is bronchiectasis) is anticipated. In support of this relationship, indices of emphysema (the other lung injury involving significant cell death after CSP) correlates with bronchiectasis. ${ }^{379}$ In addition, the remodeling of lung tissue in UIP after smoking includes a continuum of injury, which includes "traction" bronchiectasis and honeycombing. Rather than distinct entities, bronchiectasis and honeycombing reflect a spectrum of injury with the latter representing the final product after exposure of the airway to CSP. In support of this, radiographic findings typical of honeycombing and respiratory-lined cysts correspond closely with bronchiectasis histologically and they represent dilated bronchioles and alveolar ducts with apoptotic cells. ${ }^{59,380,381}$

\section{COPD}

COPD is considered to be one of the most common respiratory diseases and a leading cause of death in the world. It is defined physiologically by airflow limitation that is not fully reversible. Most commonly, COPD is considered to include some combination of $\mathrm{CB}$ and emphysema. ${ }^{180,382-384}$ Cigarette smoking is the major risk factor for developing COPD with up to $90 \%$ of the diagnosed patients being ever-smokers. Smoking cigarettes decreases all indices of lung function but particularly affects flows. ${ }^{385,386}$ The greater the number of cigarettes smoked, the faster the rate of decline in lung function and losses can be extreme in COPD patients. ${ }^{386}$

Associations of pulmonary function tests, blood and bronchoalveolar lavage endpoints, and health statistics with indices of iron homeostasis support an involvement of the metal in COPD pathogenesis. Spirometric measures can correlate positively with serum ferritin and iron concentrations as well as transferrin saturation. ${ }^{387-389}$ However, there is a negative correlation between $\mathrm{FEV}_{1}$ /FVC ratio and serum ferritin among both smokers and nonsmokers supporting a relationship between airflow obstruction and a disruption of iron homeostasis. ${ }^{390,391}$ Among COPD patients, lower percent transferrin saturation can be associated with worsening dyspnea and serum iron concentrations, transferrin saturation, hematocrit, and hemoglobin predict survival. ${ }^{392-395}$ Iron deficiency predicts acute exacerbations for COPD, while anemia increases the mortality risk four-fold in such patients. ${ }^{53,396}$ In those with COPD, anemia is an indicator for health care utilization with lower hematocrit being a risk for long-term oxygen use, hospitalization, increased duration of hospitalizations, and hospital readmission after acute exacerbation. ${ }^{392,397-399}$ Correction of iron deficiency improves dyspnea scores in one cohort of COPD patients and use of blood transfusion enables weaning from mechanical ventilation. ${ }^{51,400}$ Serum iron levels also predict susceptibility of individuals to cigarette smoke with low serum iron being associated with a decline in $\mathrm{FEV}_{1}{ }^{388}$ Bronchoalveolar lavage iron and ferritin concentrations are higher in COPD patients and in smokers without COPD when compared to nonsmokers, probably reflecting a CSP component(s) in the lavage and metal complexation, and these increase further with exacerbations. ${ }^{401}$ Finally, in addition to these pulmonary function tests, blood endpoints, and health statistics, an association between genetic 
factors and susceptibility supports a participation of iron homeostasis in COPD pathogenesis (eg, IREB2). ${ }^{402-404}$

\section{Infections}

Smokers exhibit an increased susceptibility to numerous infections. Microbials require iron to proliferate. A pathogen's survival and virulence are directly related to its success in competing for available iron and metal acquisition from the host determines the virulence of microbes. ${ }^{405,406}$ While the pathogen requires iron concentrations that approximate $10^{-6} \mathrm{M}$ for processes critical to survival, this metal is normally available in the host only at $10^{12}$. fold lower concentrations. In the lungs of a smoker, there is an increase in total concentrations of iron but a functional deficiency following complexation by CSP. However, microbes can utilize specialized systems (eg, siderophores and receptors that bind host metal transport and storage proteins) to access the sequestered iron. Subsequently, smoking elevates levels of iron available to microbes in the respiratory tract. Accordingly, smoking is the strongest risk factor for pneumonia and its severity. ${ }^{407-415}$ Similar to pneumonia, viral upper respiratory infections are increased among smokers. ${ }^{416}$ With cessation of smoking, the risk for these respiratory infections declines but remains elevated in the exsmoker, relative to the lifetime nonsmoker, because of the persistence of the CSP and complexed iron. ${ }^{410}$

\section{Conclusions}

Exposure to cigarette smoke produces a functional iron deficiency following complexation of host metal to reactive groups at the CSP surface. A component of the tissue response is focused on reversing the metal deficiency and initially is inflammatory but rapidly proceeds to include fibrosis. Structural remodeling after cigarette smoking (eg, that observed in chronic bronchitis and pulmonary fibrosis) contributes to correcting the functional iron deficiency and can be reversible. However, with significant disruption of iron homeostasis and unresolved metal deficiency, there will be injury associated with cell death, which is not reversible (eg, emphysema and bronchiectasis). The successful inhibition of a host response can potentially augment cell death and dependent injury; truly effective treatments of chronic bronchitis and pulmonary fibrosis may consequently worsen emphysema and bronchiectasis.

\section{Disclosure}

The authors report no conflicts of interest in this work.

\section{References}

1. National Research Council. Environmental Tobacco Smoke: Measuring Exposures and Assessing Health Effects. Washington DC: National Academy Press; 1986.

2. Lippmann M, Yeates DB, Albert RE. Deposition, retention, and clearance of inhaled particles. Br J Ind Med. 1980;37(4):337-362. doi:10.1136/oem.37.4.337

3. Hiller FC. Deposition of sidestream cigarette smoke in the human respiratory tract. Prev Med. 1984;13(6):602-607. doi:10.1016/ S0091-7435(84)80010-9

4. Choi JI, Kim CS. Mathematical analysis of particle deposition in human lungs: an improved single path transport model. Inhal Toxicol. 2007;19(11):925-939. doi:10.1080/08958370701513014

5. Kim SY, Sim S, Choi HG. Active and passive smoking impacts on asthma with quantitative and temporal relations: a Korean Community Health Survey. Sci Rep. 2018;8(1):8614. doi:10.1038/s41598-018-26895-3

6. Lambert AR, O'Shaughnessy P, Tawhai MH, Hoffman EA, Lin CL. Regional deposition of particles in an image-based airway model: large-eddy simulation and left-right lung ventilation asymmetry. Aerosol Sci Technol. 2011;45(1):11-25. doi:10.1080/ 02786826.2010.517578

7. Brown JS, Zeman KL, Bennett WD. Regional deposition of coarse particles and ventilation distribution in healthy subjects and patients with cystic fibrosis. J Aerosol Med. 2001;14 (4):443-454. doi:10.1089/08942680152744659

8. Heyder J. Deposition of inhaled particles in the human respiratory tract and consequences for regional targeting in respiratory drug delivery. Proc Am Thorac Soc. 2004;1(4):315-320. doi:10.1513/ pats.200409-046TA

9. Graber ER, Rudich Y. Atmospheric HULIS: how humic-like are they? A comprehensive and critical review. Atmos Chem Phys. 2006;6:729-753. doi:10.5194/acp-6-729-2006

10. Zheng GJ, He KB, Duan FK, Cheng Y, Ma YL. Measurement of humic-like substances in aerosols: a review. Environ Pollut. 2013;181:301-314. doi:10.1016/j.envpol.2013.05.055

11. Stedman RL, Chamberlain WJ, Miller RL. High molecular weight pigment in cigarette smoke. Chem Ind. 1966;37:1560-1562.

12. Ghio AJ, Stonehuerner J, Quigley DR. Humic-like substances in cigarette condensate and lung tissue of smokers. Am J Physiol. 1994;266:L382-L388. doi:10.1152/ajplung.1994.266.4.L382

13. Hoffmann D, Hoffmann I. The changing cigarette, 1950-1995. J Toxicol Environ Health. 1997;50(4):307-364. doi:10.1080/ 009841097160393

14. Gonzalez DH, Soukup JM, Madden MC, et al. A fulvic acid-like substance participates in the pro-inflammatory effects of cigarette smoke and wood smoke particles. Chem Res Toxicol. 2020;33 (4):999-1009. doi:10.1021/acs.chemrestox.0c00036

15. Vassar PS, Culling C, Saunders AM. Fluorescent histiocytes in sputum related to smoking. Arch Pathol. 1960;70:649-652.

16. Pratt SA, Finley TN, Smith MH, Ladman AJ. A comparison of alveolar macrophages and pulmonary surfactant obtained from the lungs of human smokers and nonsmokers by endobronchial lavage. Anat Rec. 1969;163(4):497-507. doi:10.1002/ar.1091630402

17. Kerenyi T, Voss B, Goeckenjan G, Muller KM. Cellular autofluorescent pigment and interstitial fibrosis in smoker's lung. Pathol Res Pract. 1992;188(7):925-930. doi:10.1016/S0344-0338(11)80253-0

18. Yue S, Ren H, Fan S, Sun Y, Wang Z, Fu P. Springtime precipitation effects on the abundance of fluorescent biological aerosol particles and HULIS in Beijing. Sci Rep. 2016;6:29618. doi:10.1038/srep29618

19. Erdogan S, Baysal A, Akba A, Hamamci C. Interaction of metals with humic acid isolated from oxidized coal. Polish J Environ Stud. 2007;16:671-675. 
20. Yang R, Van den Berg CM. Metal complexation by humic substances in seawater. Environ Sci Technol. 2009;43 (19):7192-7197. doi:10.1021/es900173w

21. Yamamoto M, Nishida A, Otsuka K, Komai T, Fukushima M. Evaluation of the binding of iron(II) to humic substances derived from a compost sample by a colorimetric method using ferrozine. Bioresour Technol. 2010;101(12):4456-4460. doi:10.1016/j. biortech.2010.01.050

22. Town RM, Duval JF, Buffle J, van Leeuwen HP. Chemodynamics of metal complexation by natural soft colloids: $\mathrm{Cu}$ (II) binding by humic acid. $J$ Phys Chem A. 2012;116(25):6489-6496. doi:10.1021/jp212226j

23. Ghio AJ, Hilborn ED, Stonehuerner JG, et al. Particulate matter in cigarette smoke alters iron homeostasis to produce a biological effect. Am J Respir Crit Care Med. 2008;178(11):1130-1138. doi:10.1164/rccm.200802-334OC

24. Zunic SS, Sekulic S, Djordjevic-Denic GV, et al. Correlation analysis of alveolar macrophage cytochemical parameters in smoking and pulmonary oncology. Int J Biol Markers. 1997;12 (2):79-82. doi:10.1177/172460089701200207

25. McGowan SE, Murray JJ, Parrish MG. Iron binding, internalization, and fate in human alveolar macrophages. J Lab Clin Med. 1986;108(6):587-595.

26. Takemoto K, Kawai H, Kuwahara T, Nishina M, Adachi S. Metal concentrations in human lung tissue, with special reference to age, sex, cause of death, emphysema and contamination of lung tissue. Int Arch Occup Environ Health. 1991;62(8):579-586. doi:10.1007/BF00381111

27. Thompson AB, Bohling T, Heires A, Linder J, Rennard SI. Lower respiratory tract iron burden is increased in association with cigarette smoking. J Lab Clin Med. 1991;117(6):493-499.

28. Wesselius LJ, Nelson ME, Skikne BS. Increased release of ferritin and iron by iron-loaded alveolar macrophages in cigarette smokers. Am J Respir Crit Care Med. 1994;150(3):690-695. doi:10.1164/ajrccm.150.3.8087339

29. Nelson ME, O’Brien-Ladner AR, Wesselius LJ. Regional variation in iron and iron-binding proteins within the lungs of smokers. Am J Respir Crit Care Med. 1996;153(4 Pt 1):1353-1358. doi:10.1164/ajrccm.153.4.8616566

30. Horniblow RD, Dowle M, Iqbal TH, et al. Alginate-iron speciation and its effect on in vitro cellular iron metabolism. PLoS One. 2015;10(9):e0138240. doi:10.1371/journal.pone.0138240

31. Colombat M, Mal H, Groussard O, et al. Pulmonary vascular lesions in end-stage idiopathic pulmonary fibrosis: histopathologic study on lung explant specimens and correlations with pulmonary hemodynamics. Hum Pathol. 2007;38(1):60-65. doi:10.1016/j.humpath.2006.06.007

32. Kim KH, Maldonado F, Ryu JH, et al. Iron deposition and increased alveolar septal capillary density in nonfibrotic lung tissue are associated with pulmonary hypertension in idiopathic pulmonary fibrosis. Respir Res. 2010;11:37. doi:10.1186/14659921-11-37

33. Puxeddu E, Comandini A, Cavalli F, et al. Iron laden macrophages in idiopathic pulmonary fibrosis: the telltale of occult alveolar hemorrhage? Pulm Pharmacol Ther. 2014;28(1):35-40. doi:10.1016/j.pupt.2013.12.002

34. McGowan SE, Henley SA. Iron and ferritin contents and distribution in human alveolar macrophages. J Lab Clin Med. 1988;111 (6):611-617.

35. Sanchez M, Sabio L, Galvez N, Capdevila M, Dominguez-Vera JM. Iron chemistry at the service of life. IUBMB Life. 2017;69 (6):382-388. doi:10.1002/iub.1602

36. Boyd PW, Jickells T, Law CS, et al. Mesoscale iron enrichment experiments 1993-2005: synthesis and future directions. Science. 2007;315(5812):612-617.
37. Carver PL. The battle for iron between humans and microbes. Curr Med Chem. 2018;25(1):85-96. doi:10.2174/09298673 24666170720110049

38. Fukuchi K, Tomoyasu S, Watanabe K, et al. Enhanced c-fos expression after intracellular iron deprivation. Biochem Mol Biol Int. 1993;30(3):403-409.

39. Ido Y, Muto N, Inada A, et al. Induction of apoptosis by hinokitiol, a potent iron chelator, in teratocarcinoma F9 cells is mediated through the activation of caspase-3. Cell Prolif. 1999;32 (1):63-73. doi:10.1046/j.1365-2184.1999.3210063.x

40. Georgiou NA, van der Bruggen T, Oudshoorn M, Hider RC, Marx JJ, van Asbeck BS. Human immunodeficiency virus type 1 replication inhibition by the bidentate iron chelators CP502 and CP511 is caused by proliferation inhibition and the onset of apoptosis. Eur J Clin Invest. 2002;32(Suppl 1):91-96. doi:10.1046/j.1365-2362.2002.0320s1091.x

41. Kakhlon O, Cabantchik ZI. The labile iron pool: characterization, measurement, and participation in cellular processes. Free Radic Biol Med. 2002;33(8):1037-1046. doi:10.1016/S0891-5849(02) 01006-7

42. Cabantchik ZI. Labile iron in cells and body fluids: physiology, pathology, and pharmacology. Front Pharmacol. 2014;5:45. doi:10.3389/fphar.2014.00045

43. Quan SG, Golde DW. Identification and localization of toxic elements in normal human lung macrophages. Proc Soc Exp Biol Med. 1981;167(2):175-181. doi:10.3181/00379727-16741145

44. Mutti A, Corradi M, Goldoni M, Vettori MV, Bernard A, Apostoli P. Exhaled metallic elements and serum pneumoproteins in asymptomatic smokers and patients with COPD or asthma. Chest. 2006;129(5):1288-1297. doi:10.1378/chest.129.5.1288

45. Mumby S, Saito J, Adcock IM, Chung KF, Quinlan GJ Decreased breath excretion of redox active iron in COPD: a protective failure? Eur Respir J. 2016;47(4):1267-1270. doi:10.1183/13993003.01710-2015

46. Ghio AJ, Soukup JM, McGee J, Madden MC, Esther CR. Iron concentration in exhaled breath condensate decreases in ever-smokers and COPD patients. J Breath Res. 2018;12 (4):046009. doi:10.1088/1752-7163/aad825

47. Wesselius LJ, Flowers CH, Skikne BS. Alveolar macrophage content of isoferritns and transferrin. Am Rev Respir Dis. 1992;145:311-316. doi:10.1164/ajrccm/145.2 Pt 1.311

48. Mateos F, Brock JH, Perez-Arellano JL. Iron metabolism in the lower respiratory tract. Thorax. 1998;53:594-600. doi:10.1136/ thx.53.7.594

49. Mayo JJ, Kohlhepp P, Zhang D, Winzerling JJ. Effects of sham air and cigarette smoke on A549 lung cells: implications for iron-mediated oxidative damage. Am J Physiol Lung Cell Mol Physiol. 2004;286(4): L866-L876. doi:10.1152/ajplung.00268.2003

50. Schaberg T, Haller H, Rau M, Kaiser D, Fassbender M, Lode H. Superoxide anion release induced by platelet-activating factor is increased in human alveolar macrophages from smokers. Eur Respir J. 1992;5(4):387-393.

51. Philippot Q, Deslee G, Adair-Kirk TL, et al. Increased iron sequestration in alveolar macrophages in chronic obstructive pulmonary disease. PLoS One. 2014;9(5):e96285. doi:10.1371/journal.pone.0096285

52. Silverberg DS, Mor R, Weu MT, Schwartz D, Schwartz IF, Chernin G. Anemia and iron deficiency in COPD patients: prevalence and the effects of correction of the anemia with erythropoiesis stimulating agents and intravenous iron. BMC Pulm Med. 2014;14:24. doi:10.1186/1471-2466-14-24

53. Nickol AH, Frise MC, Cheng HY, et al. A cross-sectional study of the prevalence and associations of iron deficiency in a cohort of patients with chronic obstructive pulmonary disease. BMJ Open. 2015;5(7):e007911. doi:10.1136/bmjopen-2015-007911 
54. Rathi V, Ish P, Singh G, Tiwari M, Goel N, Gaur SN. Iron deficiency in non-anemic chronic obstructive pulmonary disease in a predominantly male population: an ignored entity. Monaldi Arch Chest Dis. 2020;90(1). doi:10.4081/monaldi.2020.1126

55. Leifert JA. Anaemia and cigarette smoking. Int J Lab Hematol. 2008;30(3):177-184. doi:10.1111/j.1751-553X.2008.01067.x

56. Boutou AK, Stanopoulos I, Pitsiou GG, et al. Anemia of chronic disease in chronic obstructive pulmonary disease: a case-control study of cardiopulmonary exercise responses. Respiration. 2011;82(3):237-245. doi:10.1159/000326899

57. Comeche Casanova L, Echave-Sustaeta JM, Garcia Lujan R, Albarran Lozano I, Alonso Gonzalez P, Llorente Alonso MJ. Prevalence of anaemia associated with chronic obstructive pulmonary disease. Study of associated variables. Arch Bronconeumol. 2013;49 (9):383-387. doi:10.1016/j.arbres.2013.04.007

58. Vasquez A, Logomarsino JV. Anemia in chronic obstructive pulmonary disease and the potential role of iron deficiency. COPD. 2016;13(1):100-109. doi:10.3109/15412555.2015.1043519

59. Margaritopoulos GA, Vasarmidi E, Jacob J, Wells AU, Antoniou KM. Smoking and interstitial lung diseases. Eur Respir Rev. 2015;24 (137):428-435. doi:10.1183/16000617.0050-2015

60. Bak SH, Lee HY. Overlaps and uncertainties of smoking-related idiopathic interstitial pneumonias. Int J Chron Obstruct Pulmon Dis. 2017;12:3221-3229. doi:10.2147/COPD.S146899

61. Caminati A, Harari S. Smoking-related interstitial pneumonias and pulmonary Langerhans cell histiocytosis. Proc Am Thorac Soc. 2006;3(4):299-306. doi:10.1513/pats.200512-135TK

62. Rao RN, Goodman LR, Tomashefski JF Jr. Smoking-related interstitial lung disease. Ann Diagn Pathol. 2008;12(6):445-457. doi:10.1016/j.anndiagpath.2008.10.001

63. Farr GH, Harley RA, Hennigar GR. Desquamative interstitial pneumonia. An electron microscopic study. Am J Pathol. 1970;60(3):347-370.

64. Godbert B, Wissler MP, Vignaud JM. Desquamative interstitial pneumonia: an analytic review with an emphasis on aetiology. Eur Respir Rev. 2013;22(128):117-123. doi:10.1183/09059180.00005812

65. Yousem SA, Colby TV, Gaensler EA. Respiratory bronchiolitis-associated interstitial lung disease and its relationship to desquamative interstitial pneumonia. Mayo Clin Proc. 1989;64(11):1373-1380. doi:10.1016/S0025-6196(12)65379-8

66. Desai SR, Ryan SM, Colby TV. Smoking-related interstitial lung diseases: histopathological and imaging perspectives. Clin Radiol. 2003;58(4):259-268. doi:10.1016/S0009-9260(02)00525-1

67. Fraig M, Shreesha U, Savici D, Katzenstein AL. Respiratory bronchiolitis: a clinicopathologic study in current smokers, ex-smokers, and never-smokers. Am J Surg Pathol. 2002;26 (5):647-653. doi:10.1097/00000478-200205000-00011

68. Marques LJ, Teschler H, Guzman J, Costabel U. Smoker's lung transplanted to a nonsmoker. Long-term detection of smoker's macrophages. Am J Respir Crit Care Med. 1997;156 (5):1700-1702. doi:10.1164/ajrccm.156.5.9611052

69. Harmon CM, Brown N. Langerhans cell histiocytosis: a clinicopathologic review and molecular pathogenetic update. Arch Pathol Lab Med. 2015;139(10):1211-1214. doi:10.5858/ arpa.2015-0199-RA

70. Roden AC, Yi ES. Pulmonary Langerhans cell histiocytosis: an update from the pathologists' perspective. Arch Pathol Lab Med. 2016;140(3):230-240. doi:10.5858/arpa.2015-0246-RA

71. Tenenbein M, Kowalski S, Sienko A, Bowden DH, Adamson IY. Pulmonary toxic effects of continuous desferrioxamine administration in acute iron poisoning. Lancet. 1992;339(8795):699-701. doi:10.1016/0140-6736(92)90598-W

72. Ioannides AS, Panisello JM. Acute respiratory distress syndrome in children with acute iron poisoning: the role of intravenous desferrioxamine. Eur $J$ Pediatr. 2000;159(3):158-159. doi: $10.1007 / \mathrm{s} 004310050042$
73. Gau RJ, Yang HL, Suen JL, Lu FJ. Induction of oxidative stress by humic acid through increasing intracellular iron: a possible mechanism leading to atherothrombotic vascular disorder in blackfoot disease. Biochem Biophys Res Commun. 2001;283 (4):743-749. doi:10.1006/bbrc.2001.4832

74. Hseu YC, Huang HW, Wang SY, et al. Humic acid induces apoptosis in human endothelial cells. Toxicol Appl Pharmacol. 2002;182(1):34-43. doi:10.1006/taap.2002.9429

75. Cheng ML, Ho HY, Huang YW, Lu FJ, Chiu DT. Humic acid induces oxidative DNA damage, growth retardation, and apoptosis in human primary fibroblasts. Exp Biol Med. 2003;228 (4):413-423. doi:10.1177/153537020322800412

76. Yang HL, Hseu YC, Hseu YT, Lu FJ, Lin E, Lai JS. Humic acid induces apoptosis in human premyelocytic leukemia HL-60 cells. Life Sci. 2004;75(15):1817-1831. doi:10.1016/j.1fs.2004.02.033

77. Hseu YC, Lin E, Chen JY, et al. Humic acid induces G1 phase arrest and apoptosis in cultured vascular smooth muscle cells. Environ Toxicol. 2009;24(3):243-258. doi:10.1002/tox.20426

78. van Eijl S, Mortaz E, Ferreira AF, et al. Humic acid enhances cigarette smoke-induced lung emphysema in mice and IL-8 release of human monocytes. Pulm Pharmacol Ther. 2011;24 (6):682-689. doi:10.1016/j.pupt.2011.07.001

79. Ghio AJ, Tong H, Soukup JM, et al. Sequestration of mitochondrial iron by silica particle initiates a biological effect. $\mathrm{Am}$ J Physiol Lung Cell Mol Physiol. 2013;305(10):L712-L724. doi:10.1152/ajplung.00099.2013

80. Hseu YC, Senthil Kumar KJ, Chen CS, et al. Humic acid in drinking well water induces inflammation through reactive oxygen species generation and activation of nuclear factor- $\kappa \mathrm{B} / \mathrm{acti}-$ vator protein-1 signaling pathways: a possible role in atherosclerosis. Toxicol Appl Pharmacol. 2014;274(2):249-262. doi:10.1016/j.taap.2013.11.002

81. Ghio AJ, Soukup JM, Dailey LA, et al. Wood smoke particle sequesters cell iron to impact a biological effect. Chem Res Toxicol. 2015;28(11):2104-2111. doi:10.1021/acs.chemrestox.5 b00270

82. Ghio AJ, Soukup JM, Dailey LA. Air pollution particles and iron homeostasis. Biochim Biophys Acta. 2016;1860(12):2816-2825. doi:10.1016/j.bbagen.2016.05.026

83. Laughton MJ, Moroney MA, Hoult JR, Halliwell B. Effects of desferrioxamine on eicosanoid production in two intact cell systems. Biochem Pharmacol. 1989;38(1):189-193. doi:10.1016/ 0006-2952(89)90167-6

84. Hileti D, Panayiotidis P, Hoffbrand AV. Iron chelators induce apoptosis in proliferating cells. $\mathrm{Br} J$ Haematol. 1995;89 (1):181-187. doi:10.1111/j.1365-2141.1995.tb08927.x

85. Tanji K, Imaizumi $\mathrm{T}$, Matsumiya $\mathrm{T}$, et al. Desferrioxamine, an iron chelator, upregulates cyclooxygenase-2 expression and prostaglandin production in a human macrophage cell line. Biochim Biophys Acta. 2001;1530(2-3):227-235. doi:10.1016/S13881981(01)00089-0

86. Kim BS, Yoon $\mathrm{KH}, \mathrm{Oh} \mathrm{HM}$, et al. Involvement of p38 MAP kinase during iron chelator-mediated apoptotic cell death. Cell Immunol. 2002;220(2):96-106. doi:10.1016/S0008-8749(03) 00031-5

87. Lee SK, Jang HJ, Lee HJ, et al. p38 and ERK MAP kinase mediates iron chelator-induced apoptosis and -suppressed differentiation of immortalized and malignant human oral keratinocytes. Life Sci. 2006;79(15):1419-1427. doi:10.1016/j. 1fs.2006.04.011

88. Huang X, Dai J, Huang C, Zhang Q, Bhanot O, Pelle E. Deferoxamine synergistically enhances iron-mediated AP-1 activation: a showcase of the interplay between extracellular-signalregulated kinase and tyrosine phosphatase. Free Radic Res. 2007;41(10):1135-1142. doi:10.1080/10715760701609061 
89. Markel TA, Crisostomo PR, Wang M, et al. Iron chelation acutely stimulates fetal human intestinal cell production of IL-6 and VEGF while decreasing HGF: the roles of p38, ERK, and JNK MAPK signaling. Am J Physiol Gastrointest Liver Physiol. 2007;292(4):G958-G963. doi:10.1152/ajpgi.00502.2006

90. Liu Y, Cui Y, Shi M, Zhang Q, Wang Q, Chen X. Deferoxamine promotes MDA-MB-231 cell migration and invasion through increased ROS-dependent HIF-1alpha accumulation. Cell Physiol Biochem. 2014;33(4):1036-1046.

91. Zhang W, Wu Y, Yan Q, et al. Deferoxamine enhances cell migration and invasion through promotion of HIF-1alpha expression and epithelial-mesenchymal transition in colorectal cancer. Oncol Rep. 2014;31(1):111-116. doi:10.3892/or.201 3.2828

92. Niihara Y, Ge J, Shalev O, Wu H, Tu A, Tanaka KR. Desferrioxamine decreases NAD redox potential of intact red blood cells: evidence for desferrioxamine as an inducer of oxidant stress in red blood cells. BMC Clin Pharmacol. 2002;2:8. doi:10.1186/1472-6904-2-8

93. Chaston TB, Watts RN, Yuan J, Richardson DR. Potent antitumor activity of novel iron chelators derived from di-2-pyridylketone isonicotinoyl hydrazone involves Fenton-derived free radical generation. Clin Cancer Res. 2004;10(21):7365-7374. doi:10.1158/1078-0432.CCR-04-0865

94. Dendorfer A, Heidbreder M, Hellwig-Burgel T, Johren O, Qadri F, Dominiak P. Deferoxamine induces prolonged cardiac preconditioning via accumulation of oxygen radicals. Free Radic Biol Med. 2005;38(1):117-124. doi:10.1016/j.freeradbiomed.2004.10.015

95. Callens C, Coulon S, Naudin J, et al. Targeting iron homeostasis induces cellular differentiation and synergizes with differentiating agents in acute myeloid leukemia. J Exp Med. 2010;207 (4):731-750. doi:10.1084/jem.20091488

96. Nagababu E, Gulyani S, Earley CJ, Cutler RG, Mattson MP, Rifkind JM. Iron-deficiency anaemia enhances red blood cell oxidative stress. Free Radic Res. 2008;42(9):824-829. doi:10.1080/10715760802459879

97. Cakmak I, van de Wetering DA, Marschner H, Bienfait HF Involvement of superoxide radical in extracellular ferric reduction by iron-deficient bean roots. Plant Physiol. 1987;85(1):310-314. doi:10.1104/pp.85.1.310

98. Turi JL, Jaspers I, Dailey LA, et al. Oxidative stress activates anion exchange protein 2 and AP-1 in airway epithelial cells. Am J Physiol Lung Cell Mol Physiol. 2002;283(4):L791-L798. doi:10.1152/ajplung.00398.2001

99. Rose AL, Salmon TP, Lukondeh T, Neilan BA, Waite TD. Use of superoxide as an electron shuttle for iron acquisition by the marine cyanobacterium Lyngbya majuscula. Environ Sci Technol. 2005;39(10):3708-3715. doi:10.1021/es048766c

100. Choi EY, Kim EC, Oh HM, et al. Iron chelator triggers inflammatory signals in human intestinal epithelial cells: involvement of p38 and extracellular signal-regulated kinase signaling pathways. J Immunol. 2004;172(11):7069-7077. doi:10.4049/jimmunol.17 2.11.7069

101. Choi EY, Park ZY, Choi EJ, et al. Transcriptional regulation of IL-8 by iron chelator in human epithelial cells is independent from NF-kappaB but involves ERK1/2- and p38 kinase-dependent activation of AP-1. J Cell Biochem. 2007;102 (6):1442-1457. doi:10.1002/jcb.21367

102. Kim BM, Chung HW. Desferrioxamine (DFX) induces apoptosis through the p38-caspase8-Bid-Bax pathway in PHA-stimulated human lymphocytes. Toxicol Appl Pharmacol. 2008;228 (1):24-31. doi:10.1016/j.taap.2007.11.022

103. Fan Y, Wang J, Wei L, He B, Wang C, Wang B. Iron deficiency activates pro-inflammatory signaling in macrophages and foam cells via the p38 MAPK-NF-kappaB pathway. Int $J$ Cardiol. 2011;152(1):49-55. doi:10.1016/j.ijcard.2010.07.005
104. Yu Y, Richardson DR. Cellular iron depletion stimulates the JNK and p38 MAPK signaling transduction pathways, dissociation of ASK1-thioredoxin, and activation of ASK1. J Biol Chem. 2011;286(17):15413-15427. doi:10.1074/jbc.M111.225946

105. Nakagawa $H$, Tamura $T$, Mitsuda $Y$, et al. Inverse correlation between serum interleukin-6 and iron levels among Japanese adults: a cross-sectional study. BMC Hematol. 2014;14(1):6. doi:10.1186/2052-1839-14-6

106. Jeong HJ, Chung HS, Lee BR, et al. Expression of proinflammatory cytokines via HIF- $1 \alpha$ and NF- $\kappa \mathrm{B}$ activation on desferrioxamine-stimulated HMC-1 cells. Biochem Biophys Res Commun. 2003;306(4):805-811. doi:10.1016/S0006-291X(03)01073-8

107. Jeong HJ, Hong SH, Park RK, Shin T, An NH, Kim M. Hypoxiainduced IL-6 production is associated with activation of MAP kinase, HIF-1, and NF-кB on HEI-OC1 cells. Hear Res. 2005;207 (1-2):59-67. doi:10.1016/j.heares.2005.04.003

108. Jiang Y, Xue ZH, Shen WZ, et al. Desferrioxamine induces leukemic cell differentiation potentially by hypoxia-inducible factor-1 alpha that augments transcriptional activity of CCAAT/enhancer-binding protein-alpha. Leukemia. 2005;19(7):1239-1247. doi:10.1038/sj. leu. 2403734

109. Guo M, Song LP, Jiang Y, Liu W, Yu Y, Chen GQ. Hypoxiamimetic agents desferrioxamine and cobalt chloride induce leukemic cell apoptosis through different hypoxia-inducible factor$1 \alpha$ independent mechanisms. Apoptosis. 2006;11(1):67-77. doi:10.1007/s10495-005-3085-3

110. Woo KJ, Lee TJ, Park JW, Kwon TK. Desferrioxamine, an iron chelator, enhances HIF-1 $\alpha$ accumulation via cyclooxygenase-2 signaling pathway. Biochem Biophys Res Commun. 2006;343 (1):8-14. doi:10.1016/j.bbrc.2006.02.116

111. Baumann MU, Zamudio S, Illsley NP. Hypoxic upregulation of glucose transporters in BeWo choriocarcinoma cells is mediated by hypoxia-inducible factor-1. Am J Physiol Cell Physiol. 2007;293(1):C477-C485. doi:10.1152/ajpcell.00075.2007

112. Lee HJ, Lee J, Lee SK, Lee SK, Kim EC. Differential regulation of iron chelator-induced IL-8 synthesis via MAP kinase and NF$\kappa \mathrm{B}$ in immortalized and malignant oral keratinocytes. $B M C$ Cancer. 2007;7:176. doi:10.1186/1471-2407-7-176

113. Lee SK, Lee J, Min SK, et al. Iron chelator differentially activates macrophage inflammatory protein-3alpha/CCL20 in immortalized and malignant human oral keratinocytes. Arch Oral Biol. 2008;53 (9):801-809. doi:10.1016/j.archoralbio.2008.01.015

114. Lu H, Li Y, Shu M, et al. Hypoxia-inducible factor-1 $\alpha$ blocks differentiation of malignant gliomas. FEBS J. 2009;276 (24):7291-7304. doi:10.1111/j.1742-4658.2009.07441.x

115. Varesio L, Battaglia F, Raggi F, Ledda B, Bosco MC. Macrophageinflammatory protein-3 $\alpha /$ CCL-20 is transcriptionally induced by the iron chelator desferrioxamine in human mononuclear phagocytes through nuclear factor (NF)-кB. Mol Immunol. 2010;47(4):685-693. doi:10.1016/j.molimm.2009.10.031

116. Yuan G, Khan SA, Luo W, Nanduri J, Semenza GL, Prabhakar NR. Hypoxia-inducible factor 1 mediates increased expression of NADPH oxidase-2 in response to intermittent hypoxia. J Cell Physiol. 2011;226 (11):2925-2933. doi:10.1002/jcp.22640

117. Fujimoto Y, Kondo Y, Nakajima M, Takai S, Sakuma S, Fujita T. Stimulation of prostaglandin synthesis in rabbit gastric antral mucosal slices by desferrioxamine in vitro. Biochem Int. 1991;24(1):33-42.

118. Lee HJ, Choi SC, Choi EY, et al. Iron chelator inducesMIP-3 $\alpha$ / CCL20 in human intestinal epithelial cells: implication for triggering mucosal adaptive immunity. Exp Mol Med. 2005;37 (4):297-310. doi:10.1038/emm.2005.40

119. Kuschner WG, D’Alessandro A, Wong H, Blanc PD. Dosedependent cigarette smoking-related inflammatory responses in healthy adults. Eur Respir J. 1996;9(10):1989-1994. doi:10.1183/09031936.96.09101989 
120. O'Brien-Ladner AR, Blumer BM, Wesselius LJ. Differential regulation of human alveolar macrophage-derived interleukin-1 $\beta$ and tumor necrosis factor- $\alpha$ by iron. J Lab Clin Med. 1998;132 (6):497-506. doi:10.1016/S0022-2143(98)90128-7

121. O'Brien-Ladner AR, Nelson SR, Murphy WJ, Blumer BM, Wesselius LJ. Iron is a regulatory component of human IL-1 $\beta$ production. Am J Respir Cell Mol Biol. 2000;23(1):112-119. doi:10.1165/ajrcmb.23.1.3736

122. Ghio AJ, Soukup JM, Stonehuerner J, et al. Quartz disrupts iron homeostasis in alveolar macrophages to impact a pro-inflammatory effect. Chem Res Toxicol. 2019;32 (9):1737-1747. doi:10.1021/acs.chemrestox.8b00301

123. Polosa R, Thomson Nc. Smoking and asthma: dangerous liaisons. Eur Respir J. 2013;41(3):716-726. doi:10.1183/ 09031936.00073312

124. Bakakos P, Kostikas K, Loukides S. Smoking asthma phenotype: diagnostic and management challenges. Curr Opin Pulm Med. 2016;22(1):53-58. doi:10.1097/MCP.0000000000000221

125. McLeish AC, Zvolensky MJ. Asthma and cigarette smoking: a review of the empirical literature. $J$ Asthma. 2010;47 (4):345-361. doi:10.3109/02770900903556413

126. Chang JE, Ding D, Martin-Lazaro J, White A, Stevenson DD. Smoking, environmental tobacco smoke, and aspirin-exacerbated respiratory disease. Ann Allergy Asthma Immunol. 2012;108 (1):14-19. doi:10.1016/j.anai.2011.09.022

127. Pinheiro GP, Souza-Machado C, Fernandes AGO, et al. Selfreported smoking status and urinary cotinine levels in patients with asthma. J Bras Pneumol. 2018;44(6):477-485. doi:10.1590/ s1806-37562017000000018

128. Thomson NC, Chaudhuri R. Asthma in smokers: challenges and opportunities. Curr Opin Pulm Med. 2009;15(1):39-45. doi:10.1097/MCP.0b013e32831da894

129. Bittner JC, Hasegawa K, Probst BD, Mould-Millman NK, Silverman RA, Camargo CA Jr. Smoking status and smoking cessation intervention among U.S. adults hospitalized for asthma exacerbation. Allergy Asthma Proc. 2016;37(4):318-323. doi:10.2500/aap.2016.37.3952

130. Silverman RA, Hasegawa K, Egan DJ, Stiffler KA, Sullivan AF, Camargo CA. Multicenter study of cigarette smoking among adults with asthma exacerbations in the emergency department, 2011-2012. Respir Med. 2017;125:89-91. doi:10.1016/j. rmed.2017.02.004

131. Jordao E, Kuschnir FC, Figueiredo VC, et al. ERICA: smoking is associated with more severe asthma in Brazilian adolescents. J Pediatr. 2019;95(5):538-544. doi:10.1016/j.jped.2018.05.010

132. Eisner Md. Environmental tobacco smoke and adult asthma. Clin Chest Med. 2002;23(4):749-761. doi:10.1016/S0272-5231(02) 00033-3

133. Jaakkola MS, Piipari R, Jaakkola N, Jaakkola JJ. Environmental tobacco smoke and adult-onset asthma: a population-based incident case-control study. Am J Public Health. 2003;93 (12):2055-2060. doi:10.2105/AJPH.93.12.2055

134. Thomson Nc. The role of environmental tobacco smoke in the origins and progression of asthma. Curr Allergy Asthma Rep. 2007;7(4):303-309. doi:10.1007/s11882-007-0045-8

135. Eisner MD. Passive smoking and adult asthma. Immunol Allergy Clin North Am. 2008;28(3):521-537, viii. doi:10.1016/j. iac.2008.03.006

136. Pietinalho A, Pelkonen A, Rytila P. Linkage between smoking and asthma. Allergy. 2009;64(12):1722-1727. doi:10.1111/j.13989995.2009.02208.x

137. Jerzynska J, Stelmach I, Grzelewski T, Stelmach W, Krakowiak J. High exposure to passive tobacco smoking and the development of asthma in an adult patient who had never smoked. Am J Respir Crit Care Med. 2010;182(3):433-434. doi:10.1164/ajrccm.18 2.3.433
138. Thacher JD, Gehring U, Gruzieva O, et al. Maternal smoking during pregnancy and early childhood and development of asthma and rhinoconjunctivitis - a MeDALL project. Environ Health Perspect. 2018;126(4):047005. doi:10.1289/EHP2738

139. Borak J, Lefkowitz RY. Bronchial hyperresponsiveness. Occup Med. 2016;66(2):95-105. doi:10.1093/occmed/kqv158

140. O'Connor GT, Sparrow D, Segal MR, Weiss ST. Smoking, atopy, and methacholine airway responsiveness among middle-aged and elderly men. The Normative Aging Study. Am Rev Respir Dis. 1989;140(6):1520-1526. doi:10.1164/ajrccm/140.6.1520

141. Menon P, Rando RJ, Stankus RP, Salvaggio JE, Lehrer SB. Passive cigarette smoke-challenge studies: increase in bronchial hyperreactivity. J Allergy Clin Immunol. 1992;89(2):560-566. doi:10.1016/0091-6749(92)90323-T

142. Tashkin DP, Altose MD, Bleecker ER, et al. The lung health study: airway responsiveness to inhaled methacholine in smokers with mild to moderate airflow limitation. Am Rev Respir Dis. 1992;145(2 Pt 1):301-310. doi:10.1164/ajrccm/145.2_Pt_1.301

143. Nowak D, Jorres R, Schmidt A, Magnussen H. Effect of 3 hours' passive smoke exposure in the evening on airway tone and responsiveness until next morning. Int Arch Occup Environ Health. 1997;69(2):125-133. doi:10.1007/s004200050126

144. Sunyer J, Anto JM, Kogevinas M, Soriano JB, Tobias A, Munoz A. Smoking and bronchial responsiveness in nonatopic and atopic young adults. Spanish Group of the European Study of Asthma. Thorax. 1997;52(3):235-238. doi:10.1136/thx.52.3.235

145. Hodgins P, Henneberger PK, Wang ML, Petsonk EL. Bronchial responsiveness and five-year FEV1 decline: a study in miners and nonminers. Am J Respir Crit Care Med. 1998;157(5 Pt 1):1390-1396. doi:10.1164/ajrccm.157.5.9701123

146. Jensen EJ, Dahl R, Steffensen F. Bronchial reactivity to cigarette smoke; relation to lung function, respiratory symptoms, serum-immunoglobulin E and blood eosinophil and leukocyte counts. Respir Med. 2000;94(2):119-127. doi:10.1053/ rmed.1999.0664

147. den Dekker HT, Voort A, de Jongste JC, et al. Tobacco smoke exposure, airway resistance, and asthma in school-age children: the generation R study. Chest. 2015;148(3):607-617. doi:10.1378/chest.14-1520

148. Lau S, Nickel R, Niggemann B, et al. The development of childhood asthma: lessons from the German Multicentre Allergy Study (MAS). Paediatr Respir Rev. 2002;3(3):265-272. doi:10.1016/ S1526-0542(02)00189-6

149. Xepapadaki P, Manios Y, Liarigkovinos T, et al. Association of passive exposure of pregnant women to environmental tobacco smoke with asthma symptoms in children. Pediatr Allergy Immunol. 2009;20 (5):423-429. doi:10.1111/j.1399-3038.2008.00820.x

150. Neuman A, Hohmann C, Orsini N, et al. Maternal smoking in pregnancy and asthma in preschool children: a pooled analysis of eight birth cohorts. Am J Respir Crit Care Med. 2012;186 (10):1037-1043. doi:10.1164/rccm.201203-0501OC

151. Hollams EM, de Klerk NH, Holt PG, Sly PD. Persistent effects of maternal smoking during pregnancy on lung function and asthma in adolescents. Am J Respir Crit Care Med. 2014;189 (4):401-407. doi:10.1164/rccm.201302-0323OC

152. Ghio AJ. Asthma as a disruption in iron homeostasis. Biometals. 2016;29(5):751-779. doi:10.1007/s10534-016-9948-y

153. Simonsson BG, Jacobs FM, Nadel JA. Role of autonomic nervous system and the cough reflex in the increased responsiveness of airways in patients with obstructive airway disease. $J$ Clin Invest. 1967;46(11):1812-1818. doi:10.1172/JCI105671

154. Ricciardolo FL, Rado V, Fabbri LM, Sterk PJ, Di Maria GU, Geppetti P. Bronchoconstriction induced by citric acid inhalation in Guinea pigs: role of tachykinins, bradykinin, and nitric oxide. Am J Respir Crit Care Med. 1999;159(2):557-562. doi:10.1164/ ajrccm.159.2.9804022 
155. Wiles FJ, Johnston JR, Le Roux AF, Churchill AR. Acute exposure to gold mine dust-a bronchial challenge test? Ann Occup Hyg. 1982;26(1-4):663-675.

156. Cloutier Y, Lagier F, Cartier A, Malo JL. Validation of an exposure system to particles for the diagnosis of occupational asthma. Chest. 1992;102(2):402-407. doi:10.1378/chest.102.2.402

157. Wade JF 3rd, Newman LS. Diesel asthma: reactive airways disease following overexposure to locomotive exhaust. J Occup Med. 1993;35 (2):149-154. doi:10.1097/00043764-199302000-00015

158. Pateva IB, Kerling EH, Reddy M, Chen D, Carlson SE, Tancabelic J. Effect of maternal cigarette smoking on newborn iron stores. Clin Res Trials. 2015;1(1):4-7.

159. Chelchowska M, Laskowska-Klita T. Effect of maternal smoking on some markers of iron status in umbilical cord blood. Roczniki Akademii Medycznej w Bialymstoku. 2002;47:235-240.

160. Lee JH, Lee DS, Kim EK, et al. Simvastatin inhibits cigarette smoking-induced emphysema and pulmonary hypertension in rat lungs. Am J Respir Crit Care Med. 2005;172(8):987-993. doi:10.1164/rccm.200501-041OC

161. Wright JL, Levy RD, Churg A. Pulmonary hypertension in chronic obstructive pulmonary disease: current theories of pathogenesis and their implications for treatment. Thorax. 2005;60 (7):605-609. doi:10.1136/thx.2005.042994

162. Said SI, Hamidi SA, Gonzalez Bosc L. Asthma and pulmonary arterial hypertension: do they share a key mechanism of pathogenesis? Eur Respir J. 2010;35(4):730-734. doi:10.1183/ 09031936.00097109

163. Weissmann N, Grimminger F, Seeger W. Smoking: is it a risk factor for pulmonary vascular diseases? Pulm Circ. 2012;2 (4):395-396. doi:10.4103/2045-8932.105027

164. Santos S, Peinado VI, Ramirez J, et al. Characterization of pulmonary vascular remodelling in smokers and patients with mild COPD. Eur Respir J. 2002;19(4):632-638. doi:10.1183/ 09031936.02.00245902

165. Higenbottam T. Pulmonary hypertension and chronic obstructive pulmonary disease: a case for treatment. Proc Am Thorac Soc. 2005;2(1):12-19. doi:10.1513/pats.200411-053SF

166. Plesner LL, Schoos MM, Dalsgaard M, et al. Iron deficiency in COPD associates with increased pulmonary artery pressure estimated by echocardiography. Heart Lung Circ. 2017;26 (1):101-104. doi:10.1016/j.hlc.2016.04.020

167. Decker I, Ghosh S, Comhair SA, et al. High levels of zinc-protoporphyrin identify iron metabolic abnormalities in pulmonary arterial hypertension. Clin Transl Sci. 2011;4(4):253-258. doi:10.1111/j.1752-8062.2011.00301.x

168. Rhodes CJ, Howard LS, Busbridge $M$, et al. Iron deficiency and raised hepcidin in idiopathic pulmonary arterial hypertension: clinical prevalence, outcomes, and mechanistic insights. $J$ Am Coll Cardiol. 2011;58(3):300-309. doi:10.1016/j.jacc.2011.02.057

169. Ruiter G, Lankhorst $\mathrm{S}$, Boonstra A, et al. Iron deficiency is common in idiopathic pulmonary arterial hypertension. Eur Respir J. 2011;37 (6):1386-1391. doi:10.1183/09031936.00100510

170. van Empel VP, Lee J, Williams TJ, Kaye DM. Iron deficiency in patients with idiopathic pulmonary arterial hypertension. Heart Lung Circ. 2014;23(3):287-292. doi:10.1016/j.hlc.2013.08.007

171. Robinson JC, Graham BB, Rouault TC, Tuder RM. The crossroads of iron with hypoxia and cellular metabolism. Implications in the pathobiology of pulmonary hypertension. Am J Respir Cell Mol Biol. 2014;51(6):721-729. doi:10.1165/rcmb.2014-0021TR

172. Yu X, Luo Q, Liu Z, et al. Prevalence of iron deficiency in different subtypes of pulmonary hypertension. Heart Lung. 2018;47(4):308-313. doi:10.1016/j.hrtlng.2018.05.002

173. Smith TG, Balanos GM, Croft QP, et al. The increase in pulmonary arterial pressure caused by hypoxia depends on iron status. J Physiol. 2008;586(24):5999-6005. doi:10.1113/jphysiol.200 8.160960
174. Smith TG, Talbot NP, Privat C, et al. Effects of iron supplementation and depletion on hypoxic pulmonary hypertension: two randomized controlled trials. JAMA. 2009;302(13):1444-1450. doi:10.1001/jama.2009.1404

175. Rhodes CJ, Wharton J, Howard L, Gibbs JS, Vonk-Noordegraaf A, Wilkins MR. Iron deficiency in pulmonary arterial hypertension: a potential therapeutic target. Eur Respir J. 2011;38 (6):1453-1460. doi:10.1183/09031936.00037711

176. Bart NK, Curtis MK, Cheng HY, et al. Elevation of iron storage in humans attenuates the pulmonary vascular response to hypoxia. $\mathrm{JAppl}$ Physiol. 2016;121(2):537-544. doi:10.1152/japplphysiol.00032.2016

177. Lakhal-Littleton S, Crosby A, Frise MC, et al. Intracellular iron deficiency in pulmonary arterial smooth muscle cells induces pulmonary arterial hypertension in mice. Proc Natl Acad Sci U S A. 2019;116 (26):13122-13130. doi:10.1073/pnas.1822010116

178. Cotroneo E, Ashek A, Wang L, et al. Iron homeostasis and pulmonary hypertension: iron deficiency leads to pulmonary vascular remodeling in the rat. Circ Res. 2015;116(10):1680-1690. doi:10.1161/CIRCRESAHA.116.305265

179. Eguchi A, Naito Y, Iwasaku T, et al. Association of dietary iron restriction with left ventricular remodeling after myocardial infarction in mice. Heart Vessels. 2016;31(2):222-229. doi:10.1007/s00380-014-0621-5

180. Kim V, Criner GJ. Chronic bronchitis and chronic obstructive pulmonary disease. Am J Respir Crit Care Med. 2013;187 (3):228-237. doi:10.1164/rccm.201210-1843CI

181. Kaisheva NS, Kaishev AS. Cation-exchange properties of S-metal polyuronates. Pharm Chem J. 2014;48(4):284-287. doi:10.1007/ s11094-014-1095-6

182. Curran RC, Clark AE, Lovell D. Acid mucopolysaccharides in electron microscopy. The use of the colloidal iron method. J Anat. 1965;99(Pt 3):427-434.

183. Yardley JH, Brown GD. Fibroblasts in tissue culture. Use of colloidal iron for ultrastructural localization of acid mucopolysaccharides. Lab Invest. 1965;14:501-513.

184. Bohacek L, Gupta R. A simple colloidal iron stain for demonstration of acid mucopolysacchrides in mammalian tissues. Am J Med Technol. 1968;34(5):287-288.

185. Sorvari TE. Histochemical observations on the role of ferric chloride in the high-iron diamine technique for localizing sulphated mucosubstances. Histochem J. 1972;4(3):193-204. doi:10.1007/BF01890991

186. Takagi M, Parmley RT, Spicer SS, Denys FR, Setser ME. Ultrastructural localization of acidic glycoconjugates with the low iron diamine method. J Histochem Cytochem. 1982;30 (5):471-476. doi:10.1177/30.5.6176615

187. Seno S, Tsujii T, Ono T, Ukita S. Cationic cacodylate iron colloid for the detection of anionic sites on cell surface and the histochemical stain of acid mucopolysaccharides. Histochemistry. 1983;78(1):27-31. doi:10.1007/BF00491108

188. Campo GM, Avenoso A, D'Ascola A, et al. Purified human plasma glycosaminoglycans limit oxidative injury induced by iron plus ascorbate in skin fibroblast cultures. Toxicol in Vitro. 2005;19(5):561-572. doi:10.1016/j.tiv.2005.03.003

189. Bai M, Han W, Zhao X, Wang Q, Gao Y, Deng S. Glycosaminoglycans from a sea snake (Lapemis curtus): extraction, structural characterization and antioxidant activity. Mar Drugs. 2018;16(5):170. doi:10.3390/md16050170

190. Haug A, Smidsrod O. The effect of divalent metals on the properties of alginate solutions. II. Comparison of different metal ions. Acta Chemica Scandinavica. 1965;19:341-351. doi:10.3891/acta. chem.scand.19-0341

191. Murakami T, Ohtsuka A, Taguchi T. Neurons with intensely negatively charged extracellular matrix in the human visual cortex. Arch Histol Cytol. 1994;57(5):509-522. doi:10.1679/ aohc.57.509 
192. Deiana S, Palma A, Premoli A, Senette C. Possible role of the polyuronic components in accumulation and mobilization of iron and phosphate at the soil-root interface. Plant Physiol Bioch. 2007;45(5):341-349. doi:10.1016/j.plaphy.2007.03.025

193. Vyshtakaliuk AB, Zobov VV, Minzanova ST, et al. Antianemic activity of water-soluble $\mathrm{Na}, \mathrm{Ca}, \mathrm{Fe}$-polygalacturonate. Bull Exp Biol Med. 2010;150(1):45-47. doi:10.1007/s10517-010-1064-3

194. Auerbach H, Giammanco GE, Schunemann V, Ostrowski AD, Carrano CJ. Mossbauer spectroscopic characterization of iron(III)-polysaccharide coordination complexes: photochemistry, biological, and photoresponsive materials implications. Inorg Chem. 2017;56(19):11524-11531. doi:10.1021/acs.inorgchem.7 b00686

195. Maire Du Poset A, Lerbret A, Zitolo A, Cousin F, Assifaoui A. Design of polygalacturonate hydrogels using iron(II) as cross-linkers: a promising route to protect bioavailable iron against oxidation. Carbohydr Polym. 2018;188:276-283. doi:10.1016/j.carbpol.2018.02.007

196. Gunter EA, Popeyko OV, Melekhin AK, Belozerov VS, Martinson EA, Litvinets SG. Preparation and properties of the pectic gel microparticles based on the $\mathrm{Zn}(2+), \mathrm{Fe}(3+)$ and $\mathrm{Al}(3+)$ cross-linking cations. Int J Biol Macromol. 2019;138:629-635. doi:10.1016/j.ijbiomac.2019.07.122

197. Maire Du Poset A, Lerbret A, Boue F, Zitolo A, Assifaoui A, Cousin F. Tuning the structure of galacturonate hydrogels: external gelation by $\mathrm{Ca}, \mathrm{Zn}$, or $\mathrm{Fe}$ cationic cross-linkers. Biomacromolecules. 2019;20(7):2864-2872. doi:10.1021/acs. biomac. $9 \mathrm{~b} 00726$

198. Chimisso V, Conti S, Kong P, Fodor C, Meier WP. Metal cation responsive anionic microgels: behaviour towards biologically relevant divalent and trivalent ions. Soft Matter. 2021;17 (3):715-723. doi:10.1039/D0SM01458C

199. Kohn R. Ion binding on polyuronates - alginate and pectin. Pure Appl Chem. 1975;42(3):371-397. doi:10.1351/pac197542030371

200. Sreeram KJ, Yamini Shrivastava H, Nair BU. Studies on the nature of interaction of iron(III) with alginates. Biochim Biophys Acta. 2004;1670(2):121-125. doi:10.1016/j.bbagen.2003.11.001

201. Zhang JQ, Chen $\mathrm{C}, \mathrm{Fu} \mathrm{X}$. Fructus mori L. polysaccharide-iron chelates formed by self-embedding with iron(III) as the core exhibit good antioxidant activity. Food Funct. 2019;10 (6):3150-3160. doi:10.1039/C9FO00540D

202. Laparra JM, Tako E, Glahn RP, Miller DD. Isolated glycosaminoglycans from cooked haddock enhance nonheme iron uptake by Caco-2 cells. J Agric Food Chem. 2008;56(21):10346-10351. doi:10.1021/jf8015927

203. Laparra JM, Barbera R, Alegria A, Glahn RP, Miller DD. Purified glycosaminoglycans from cooked haddock may enhance Fe uptake via endocytosis in a Caco-2 cell culture model. J Food Sci. 2009;74(6):H168-H173. doi:10.1111/j.1750-3841.20 09.01216.x

204. Wang H, Betti M. Sulfated glycosaminoglycan-derived oligosaccharides produced from chicken connective tissue promote iron uptake in a human intestinal Caco-2 cell line. Food Chem. 2017;220:460-469. doi:10.1016/j.foodchem.2016.10.025

205. Tease BE, Walker RW. Comparative composition of the sheath of the cyanobacterium Gloeothece ATCC-27152 cultured with and without combined nitrogen. J Gen Microbiol. 1987;133:3 331-3339.

206. Hassler CS, Schoemann V, Nichols CM, Butler EC, Boyd PW. Saccharides enhance iron bioavailability to Southern Ocean phytoplankton. Proc Natl Acad Sci U S A. 2011;108 (3):1076-1081. doi:10.1073/pnas.1010963108

207. Li ZK, Dai GZ, Juneau P, Qiu BS. Capsular polysaccharides facilitate enhanced iron acquisition by the colonial cyanobacterium Microcystis sp. isolated from a freshwater lake. J Phycol. 2016;52(1):105-115. doi:10.1111/jpy.12372
208. Haug A, Smidsrød O. Fractionation of alginates by precipitation with calcium and magnesium ions. Acta Chem Scand. 1965;19:1221-1226. doi:10.3891/acta.chem.scand.19-1221

209. Thibault JF, Rinaudo M. Chain association of pectic molecules during calcium-induced gelation. Biopolymers. 1986;25 (3):455-468. doi:10.1002/bip.360250306

210. Yang Y, Zhang GY, Hong Y, Gu ZB, Fang F. Calcium cation triggers and accelerates the gelation of high methoxy pectin. Food Hydrocolloid. 2013;32(2):228-234. doi:10.1016/j.foodhyd.20 13.01.003

211. De Philippis R, Margheri MC, Materassi R, Vincenzini M. Potential of unicellular cyanobacteria from saline environments as exopolysaccharide producers. Appl Environ Microb. 1998;64 (3):1130-1132. doi:10.1128/AEM.64.3.1130-1132.1998

212. De Philippis R, Sili C, Paperi R, Vincenzini M. Exopolysaccharide-producing cyanobacteria and their possible exploitation: a review. J Appl Phycol. 2001;13(4):293-299. doi:10.1023/A:1017590425924

213. Pradhan S, Singh S, Rai LC. Characterization of various functional groups present in the capsule of Microcystis and study of their role in biosorption of Fe, Ni and Cr. Bioresource Technol. 2007;98(3):595-601. doi:10.1016/j.biortech.2006.02.041

214. Vartivarian SE, Anaissie EJ, Cowart RE, Sprigg HA, Tingler MJ, Jacobson ES. Regulation of cryptococcal capsular polysaccharide by iron. J Infect Dis. 1993;167(1):186-190. doi:10.1093/infdis/ 167.1.186

215. Vartivarian SE, Cowart RE, Anaissie EJ, Tashiro T, Sprigg HA. Iron acquisition by Cryptococcus neoformans. J Med Vet Mycol. 1995;33(3):151-156. doi:10.1080/02681219580000331

216. Moreira LO, Andrade AF, Vale MD, et al. Effects of iron limitation on adherence and cell surface carbohydrates of Corynebacterium diphtheriae strains. Appl Environ Microbiol. 2003;69 (10):5907-5913. doi:10.1128/AEM.69.10.5907-5913.2003

217. Lian T, Simmer MI, D’Souza CA, et al. Iron-regulated transcription and capsule formation in the fungal pathogen Cryptococcus neoformans. Mol Microbiol. 2005;55(5):1452-1472. doi:10.1111/ j.1365-2958.2004.04474.x

218. Rolerson E, Swick A, Newlon L, et al. The SloR/Dlg metalloregulator modulates Streptococcus mutans virulence gene expression. J Bacteriol. 2006;188(14):5033-5044. doi:10.1128/ JB.00155-06

219. Bush DS, Mccoll JG. Mass-action expressions of ion-exchange applied to $\mathrm{Ca}-2+, \mathrm{H}+, \mathrm{K}+$, and $\mathrm{Mg}-2+$ sorption on isolated cells walls of leaves from Brassica-Oleracea. Plant Physiol. 1987;85 (1):247-260. doi:10.1104/pp.85.1.247

220. Moelling C, Oberschlacke R, Ward P, et al. Metal-dependent repression of siderophore and biofilm formation in Actinomyces naeslundii. FEMS Microbiol Lett. 2007;275(2):214-220. doi:10.1111/j.1574-6968.2007.00888.x

221. Grant MR, Tymon LS, Helms GL, Thomashow LS, Kent Keller C, Harsh JB. Biofilm adaptation to iron availability in the presence of biotite and consequences for chemical weathering. Geobiology. 2016;14(6):588-598. doi:10.1111/gbi.12187

222. Wiens JR, Vasil AI, Schurr MJ, Vasil ML. Iron-regulated expression of alginate production, mucoid phenotype, and biofilm formation by Pseudomonas aeruginosa. mBio. 2014;5(1):e01010e01013. doi:10.1128/mBio.01010-13

223. Johnson M, Cockayne A, Williams PH, Morrissey JA. Ironresponsive regulation of biofilm formation in staphylococcus aureus involves fur-dependent and fur-independent mechanisms. $J$ Bacteriol. 2005;187(23):8211-8215. doi:10.1128/JB.187.23.8 211-8215.2005

224. Musk DJ, Banko DA, Hergenrother PJ. Iron salts perturb biofilm formation and disrupt existing biofilms of Pseudomonas aeruginosa. Chem Biol. 2005;12(7):789-796. doi:10.1016/j. chembiol.2005.05.007 
225. Yang L, Barken KB, Skindersoe ME, Christensen AB, Givskov M, Tolker-Nielsen T. Effects of iron on DNA release and biofilm development by Pseudomonas aeruginosa. Microbiology. 2007;153 (Pt5):1318-1328. doi:10.1099/mic.0.2006/004911-0

226. Hindre $T$, Bruggemann $H$, Buchrieser $C$, Hechard $Y$. Transcriptional profiling of Legionella pneumophila biofilm cells and the influence of iron on biofilm formation. Microbiology. 2008;154(Pt1):30-41. doi:10.1099/mic.0.2007/ 008698-0

227. Oglesby-Sherrouse AG, Djapgne L, Nguyen AT, Vasil AI, Vasil ML. The complex interplay of iron, biofilm formation, and mucoidy affecting antimicrobial resistance of Pseudomonas aeruginosa. Pathog Dis. 2014;70(3):307-320. doi:10.1111/2049$632 X .12132$

228. Oliveira F, Franca A, Cerca N. Staphylococcus epidermidis is largely dependent on iron availability to form biofilms. Int J Med Microbiol. 2017;307(8):552-563. doi:10.1016/j. ijmm.2017.08.009

229. Quarterman J. Metal absorption and the intestinal mucus layer. Digestion. 1987;37(1):1-9. doi:10.1159/000199480

230. Xu SS, Lin SZ, Lai ZX. Cadmium impairs iron homeostasis in Arabidopsis thaliana by increasing the polysaccharide contents and the iron-binding capacity of root cell walls. Plant Soil. 2015;392:71-85. doi:10.1007/s11104-015-2443-3

231. Simovich M, Hainsworth LN, Fields PA, Umbreit JN, Conrad ME. Localization of the iron transport proteins Mobilferrin and DMT-1 in the duodenum: the surprising role of mucin. Am J Hematol. 2003;74(1):32-45. doi:10.1002/ajh.10383

232. Hardin JH, Spicer SS. Ultrastructural localization of dialyzed iron-reactive mucosubstance in rabbit heterophils, basophils, and eosinophils. J Cell Biol. 1971;48(2):368-386. doi:10.1083/ jcb.48.2.368

233. Yao X, Yao X, Xu K, et al. Trivalent iron induced gelation in Artemisia sphaerocephala Krasch. polysaccharide. Int J Biol Macromol. 2020;144:690-697. doi:10.1016/j.ijbiomac.2019.12.123

234. Niu R, Qin Z, Ji F, et al. Hybrid pectin-Fe(3+)/polyacrylamide double network hydrogels with excellent strength, high stiffness, superior toughness and notch-insensitivity. Soft Matter. 2017;13 (48):9237-9245. doi:10.1039/C7SM02005H

235. Wang $\mathrm{P}$, Zhang $\mathrm{W}$, Yang R, et al. Biomimetic poly $(\gamma$-glutamic acid) hydrogels based on iron (III) ligand coordination for cartilage tissue engineering. Int $J$ Biol Macromol. 2021;167:1508-1516. doi:10.1016/j.ijbiomac.2020.11.105

236. Peric L, Pereira CS, Perez S, Hunenberger PH. Conformation, dynamics and ion-binding properties of single-chain polyuronates: a molecular dynamics study. Mol Simulat. 2008;34 (4):421-446. doi:10.1080/08927020701759699

237. Gawkowska D, Cybulska J, Zdunek A. Structure-related gelling of pectins and linking with other natural compounds: a review. Polymers. 2018;10(7):762. doi:10.3390/polym10070762

238. Hofmann H, Schmut O. The inability of superoxide dismutase to inhibit the depolymerization of hyaluronic acid by ferrous ions and ascorbate. Albrecht Von Graefes Arch Klin Exp Ophthalmol. 1980;214(3):181-185. doi:10.1007/BF00414560

239. Balogh GT, Illes J, Szekely Z, Forrai E, Gere A. Effect of different metal ions on the oxidative damage and antioxidant capacity of hyaluronic acid. Arch Biochem Biophys. 2003;410 (1):76-82. doi:10.1016/S0003-9861(02)00661-6

240. Pornsunthorntawee $O$, Katepetch C, Vanichvattanadecha $C$, Saito N, Rujiravanit R. Depolymerization of chitosan-metal complexes via a solution plasma technique. Carbohydr Polym. 2014;102:504-512. doi:10.1016/j.carbpol.2013.11.025

241. Zhang XH, Zhang Q, Long JX, et al. Phenolics production through catalytic depolymerization of alkali lignin with metal chlorides. Bioresources. 2014;9(2):3347-3360. doi:10.15376/ biores.9.2.3347-3360
242. Shu R, Long J, Yuan Z, et al. Efficient and product-controlled depolymerization of lignin oriented by metal chloride cooperated with Pd/C. Bioresour Technol. 2015;179:84-90. doi:10.1016/j. biortech.2014.12.021

243. Dou W, Wei D, Li H, et al. Purification and characterisation of a bifunctional alginate lyase from novel Isoptericola halotolerans CGMCC 5336. Carbohydr Polym. 2013;98(2):1476-1482. doi:10.1016/j.carbpol.2013.07.050

244. Zhu X, Li X, Shi H, et al. Characterization of a novel alginate lyase from marine bacterium Vibrio furnissii H1. Mar Drugs. 2018;16(1):30.

245. Cao J. The pectin lyases in Arabidopsis thaliana: evolution, selection and expression profiles. PLoS One. 2012;7(10):e46944. doi:10.1371/journal.pone.0046944

246. Huang G, Wen S, Liao S, et al. Characterization of a bifunctional alginate lyase as a new member of the polysaccharide lyase family 17 from a marine strain BP-2. Biotechnol Lett. 2019;41 (10):1187-1200. doi:10.1007/s10529-019-02722-1

247. Ferreira V, da Silva R, Silva D, Gomes E. Production of pectate lyase by Penicillium viridicatum RFC3 in solid-state and submerged fermentation. Int $J$ Microbiol. 2010;2010:1-8. doi:10.1155/2010/276590

248. Franza T, Sauvage C, Expert D. Iron regulation and pathogenicity in Erwinia chrysanthemi 3937: role of the Fur repressor protein. Mol Plant Microbe Interact. 1999;12(2):119-128. doi:10.1094/ MPMI.1999.12.2.119

249. Franza T, Michaud-Soret I, Piquerel P, Expert D. Coupling of iron assimilation and pectinolysis in Erwinia chrysanthemi 3937. Mol Plant Microbe Interact. 2002;15(11):1181-1191. doi:10.1094/ MPMI.2002.15.11.1181

250. Asperti M, Stuemler T, Poli M, et al. Heparanase overexpression reduces hepcidin expression, affects iron homeostasis and alters the response to inflammation. PLoS One. 2016;11(10):e0164183. doi:10.1371/journal.pone. 0164183

251. Ou K, Liu Y, Zhang L, et al. Effect of neutrase, alcalase, and papain hydrolysis of whey protein concentrates on iron uptake by Caco-2 cells. J Agric Food Chem. 2010;58(8):4894-4900. doi:10.1021/jf100055y

252. Bender J, Rodriguez-Eaton S, Ekanemesang UM, Phillips P. Characterization of metal-binding bioflocculants produced by the cyanobacterial component of mixed microbial mats. Appl Environ Microbiol. 1994;60(7):2311-2315. doi:10.1128/ aem.60.7.2311-2315.1994

253. Reddy KJ, Soper BW, Tang J, Bradley RL. Phenotypic variation in exopolysaccharide production in the marine, aerobic nitrogen-fixing unicellular cyanobacterium Cyanothece sp. World J Microbiol Biotechnol. 1996;12(4):311-318. doi:10.1007/BF00340206

254. Pereira S, Micheletti E, Zille A, et al. Using extracellular polymeric substances (EPS)-producing cyanobacteria for the bioremediation of heavy metals: do cations compete for the EPS functional groups and also accumulate inside the cell? Microbiology. 2011;157(Pt 2):451-458. doi:10.1099/ mic.0.041038-0

255. Wien EM, Vancampen DR. Mucus and iron-absorption regulation in rats fed various levels of dietary iron. J Nutr. 1991;121 (1):92-100. doi:10.1093/jn/121.1.92

256. Hale CW. Histochemical demonstration of acid polysaccharides in animal tissues. Nature. 1946;157:802. doi:10.1038/157802a0

257. Berenbaum MC. The staining of bacterial capsules and slime with ferric compounds. $J$ Clin Pathol. 1955;8(4):343-344. doi:10.1136/jep.8.4.343

258. Wetzel MG, Wetzel BK, Spicer SS. Ultrastructural localization of acid mucosubstances in the mouse colon with iron-containing stains. J Cell Biol. 1966;30(2):299-315. doi:10.1083/jcb.30.2.299 
259. Sannes PL. Cytochemical visualization of anions in collagenous and elastic fiber-associated connective tissue matrix in neonatal and adult rat lungs using iron-containing stains. Histochemistry. 1986;84(1):49-56. doi:10.1007/BF00493420

260. Ohtsuka A, Murakami T. Anionic sites on the free surface of the peritoneal mesothelium: light and electron microscopic detection using cationic colloidal iron. Arch Histol Cytol. 1994;57 (4):307-315. doi:10.1679/aohc.57.307

261. McCarthy C, Reid L, Gibbons RA. Intra-alveolar mucus-removal by macrophages: with iron accumulation. J Pathol Bacteriol. 1964;87:39-47. doi:10.1002/path.1700870106

262. Craig PJ, Wells AU, Doffman S, et al. Desquamative interstitial pneumonia, respiratory bronchiolitis and their relationship to smoking. Histopathology. 2004;45(3):275-282. doi:10.1111/ j.1365-2559.2004.01921.x

263. Tazelaar HD, Wright JL, Churg A. Desquamative interstitial pneumonia. Histopathology. 2011;58(4):509-516. doi:10.1111/ j.1365-2559.2010.03649.x

264. Attili AK, Kazerooni EA, Gross BH, Flaherty KR, Myers JL, Martinez FJ. Smoking-related interstitial lung disease: radiologic-clinical-pathologic correlation. Radiographics. 2008;28 (5):1383-1396; discussion 96-98. doi:10.1148/rg.285075223

265. Marten K, Milne D, Antoniou KM, et al. Non-specific interstitial pneumonia in cigarette smokers: a CT study. Eur Radiol. 2009;19 (7):1679-1685. doi:10.1007/s00330-009-1308-7

266. Katzenstein AL, Mukhopadhyay S, Zanardi C, Dexter E. Clinically occult interstitial fibrosis in smokers: classification and significance of a surprisingly common finding in lobectomy specimens. Hum Pathol. 2010;41(3):316-325. doi:10.1016/j. humpath.2009.09.003

267. Washko GR, Hunninghake GM, Fernandez IE, et al. Lung volumes and emphysema in smokers with interstitial lung abnormalities. $\quad N$ Engl $J$ Med. 2011;364(10):897-906. doi:10.1056/NEJMoa1007285

268. Romero S, Barroso E, Rodriguez-Paniagua M, Aranda FI. Organizing pneumonia adjacent to lung cancer: frequency and clinico-pathologic features. Lung Cancer. 2002;35(2):195-201. doi:10.1016/S0169-5002(01)00405-6

269. Barroso E, Hernandez L, Gil J, Garcia R, Aranda I, Romero S. Idiopathic organizing pneumonia: a relapsing disease. 19 years of experience in a hospital setting. Respiration. 2007;74(6):624-631. doi:10.1159/000103240

270. Sveinsson OA, Isaksson HJ, Sigvaldason A, Yngvason F, Aspelund T, Gudmundsson G. Clinical features in secondary and cryptogenic organising pneumonia. Int J Tuberc Lung Dis. 2007;11(6):689-694.

271. Pardo J, Panizo A, Sola I, Queipo F, Martinez-Penuela A, Carias R. Prognostic value of clinical, morphologic, and immunohistochemical factors in patients with bronchiolitis obliterans-organizing pneumonia. Hum Pathol. 2013;44 (5):718-724. doi:10.1016/j.humpath.2012.07.016

272. Huo Z, Feng R, Tian X, Zhang H, Huo L, Liu H. Clinicopathological findings of focal organizing pneumonia: a retrospective study of 37 cases. Int J Clin Exp Pathol. 2015;8(1):511-516.

273. Yilmaz S, Akinci Ozyurek B, Erdogan Y, et al. Retrospective evaluation of patients with organizing pneumonia: is cryptogenic organizing pneumonia different from secondary organizing pneumonia? Tuberk Toraks. 2017;65(1):1-8. doi:10.5578/tt.53938

274. Iwai K, Mori T, Yamada N, Yamaguchi M, Hosoda Y. Idiopathic pulmonary fibrosis. Epidemiologic approaches to occupational exposure. Am J Respir Crit Care Med. 1994;150(3):670-675. doi:10.1164/ajrccm.150.3.8087336

275. Hubbard R, Lewis S, Richards K, Johnston I, Britton J. Occupational exposure to metal or wood dust and aetiology of cryptogenic fibrosing alveolitis. Lancet. 1996;347(8997):284-289. doi:10.1016/S01406736(96)90465-1
276. Baumgartner KB, Samet JM, Stidley CA, Colby TV, Waldron JA. Cigarette smoking: a risk factor for idiopathic pulmonary fibrosis. Am J Respir Crit Care Med. 1997;155(1):242-248. doi:10.1164/ ajrccm.155.1.9001319

277. Smith M, Dalurzo M, Panse P, Parish J, Leslie K. Usual interstitial pneumonia-pattern fibrosis in surgical lung biopsies. Clinical, radiological and histopathological clues to aetiology. $J$ Clin Pathol. 2013;66(10):896-903. doi:10.1136/jclinpath2013-201442

278. Beardsley B, Rassl D. Fibrosing organising pneumonia. J Clin Pathol. 2013;66(10):875-881. doi:10.1136/jclinpath-2012201342

279. Cottin V, Donsbeck AV, Revel D, Loire R, Cordier JF. Nonspecific interstitial pneumonia. Individualization of a clinicopathologic entity in a series of 12 patients. Am J Respir Crit Care Med. 1998;158(4):1286-1293. doi:10.1164/ ajrccm.158.4.9802119

280. Rabeyrin M, Thivolet F, Ferretti GR, et al. Usual interstitial pneumonia end-stage features from explants with radiologic and pathological correlations. Ann Diagn Pathol. 2015;19 (4):269-276. doi:10.1016/j.anndiagpath.2015.05.003

281. Moon J, Du Bois RM, Colby TV, Hansell DM, Nicholson AG. Clinical significance of respiratory bronchiolitis on open lung biopsy and its relationship to smoking related interstitial lung disease. Thorax. 1999;54(11):1009-1014. doi:10.1136/thx.54.11.1009

282. Wells AU, Nicholson AG, Hansell DM. Challenges in pulmonary fibrosis. 4: smoking-induced diffuse interstitial lung diseases. Thorax. 2007;62(10):904-910. doi:10.1136/thx.2004.031021

283. Walsh SL, Hansell DM. Diffuse interstitial lung disease: overlaps and uncertainties. Eur Radiol. 2010;20(8):1859-1867. doi:10.1007/s00330-010-1737-3

284. Todd NW, Galvin JR, Sachdeva A, Luzina IG, Atamas SP, Burke AP. Microscopic organizing pneumonia and cellular non-specific interstitial pneumonia are widespread in macroscopically normal-appearing lung tissue in idiopathic pulmonary fibrosis. J Heart Lung Transplant. 2016;35(11):1367-1370. doi:10.1016/j.healun.2016.07.014

285. Katzenstein AL, Zisman DA, Litzky LA, Nguyen BT, Kotloff RM. Usual interstitial pneumonia: histologic study of biopsy and explant specimens. Am J Surg Pathol. 2002;26 (12):1567-1577. doi:10.1097/00000478-200212000-00004

286. Du Bois R, King TE Jr. Challenges in pulmonary fibrosis x 5: the NSIP/UIP debate. Thorax. 2007;62(11):1008-1012. doi:10.1136/ thx.2004.031039

287. Fang X, Luo B, Yi X, et al. Usual interstitial pneumonia coexisted with nonspecific interstitial pneumonia, What's the diagnosis? Diagn Pathol. 2012;7:167. doi:10.1186/1746-1596-7-167

288. Li XR, Peng SC, Wei LQ. Nonspecific interstitial pneumonia overlaps organizing pneumonia in lung-dominant connective tissue disease. Int J Clin Exp Pathol. 2015;8(9):11230-11235.

289. Todd NW, Marciniak ET, Sachdeva A, et al. Organizing pneumonia/non-specific interstitial pneumonia overlap is associated with unfavorable lung disease progression. Respir Med. 2015;109(11):1460-1468. doi:10.1016/j.rmed.2015.09.015

290. Huo Z, Li J, Li S, et al. Organizing pneumonia components in non-specific interstitial pneumonia (NSIP): a clinicopathological study of 33 NSIP cases. Histopathology. 2016;68(3):347-355. doi:10.1111/his.12761

291. Miller ER, Putman RK, Vivero M, et al. Histopathology of interstitial lung abnormalities in the context of lung nodule resections. Am J Respir Crit Care Med. 2018;197(7):955-958. doi:10.1164/ rccm.201708-1679LE

292. Hung YP, Hunninghake GM, Miller ER, et al. Incidental nonneoplastic parenchymal findings in patients undergoing lung resection for mass lesions. Hum Pathol. 2019;86:93-101. doi:10.1016/ j.humpath.2019.01.002 
293. Hatabu H, Hunninghake GM, Richeldi L, et al. Interstitial lung abnormalities detected incidentally on CT: a Position Paper from the Fleischner Society. Lancet Respir Med. 2020;8(7):726-737. doi:10.1016/S2213-2600(20)30168-5

294. Jin GY, Lynch D, Chawla A, et al. Interstitial lung abnormalities in a CT lung cancer screening population: prevalence and progression rate. Radiology. 2013;268(2):563-571. doi:10.1148/ radiol.13120816

295. Araki T, Putman RK, Hatabu H, et al. Development and progression of interstitial lung abnormalities in the Framingham Heart Study. Am J Respir Crit Care Med. 2016;194(12):1514-1522. doi:10.1164/rccm.201512-2523OC

296. Podolanczuk AJ, Oelsner EC, Barr RG, et al. High attenuation areas on chest computed tomography in community-dwelling adults: the Mesa study. Eur Respir J. 2016;48(5):1442-1452. doi:10.1183/13993003.00129-2016

297. Iwasawa T, Takemura T, Ogura T. Smoking-related lung abnormalities on computed tomography images: comparison with pathological findings. Jpn J Radiol. 2018;36(3):165-180. doi:10.1007/ s11604-017-0713-0

298. B Moore B, Lawson WE, Oury TD, et al. Animal models of fibrotic lung disease. Am J Respir Cell Mol Biol. 2013;49 (2):167-179. doi:10.1165/rcmb.2013-0094TR

299. Corradi M, Acampa O, Goldoni M, et al. Metallic elements in exhaled breath condensate of patients with interstitial lung diseases. J Breath Res. 2009;3(4):046003. doi:10.1088/17527155/3/4/046003

300. Wright PH, Buxton-Thomas M, Kreel L, Steel SJ. Cryptogenic fibrosing alveolitis: pattern of disease in the lung. Thorax 1984;39(11):857-861. doi:10.1136/thx.39.11.857

301. Vieyra-Reyes P, Oros-Pantoja R, Torres-Garcia E, Gutierrez-Ruiz A, Perez-Honorato J. (67)Ga as a biosensor of iron needs in different organs: study performed on male and female rats subjected to iron deficiency and exercise. J Trace Elem Med Biol. 2017;44:93-98. doi:10.1016/j.jtemb.2017.06.007

302. Haslam PL, Parker DJ, Townsend PJ. Increases in HLA-DQ, DP, $\mathrm{DR}$, and transferrin receptors on alveolar macrophages in sarcoidosis and allergic alveolitis compared with fibrosing alveolitis. Chest. 1990;97(3):651-661. doi:10.1378/chest.97.3.651

303. Bharat A, Bhorade SM, Morales-Nebreda L, et al. Flow cytometry reveals similarities between lung macrophages in humans and mice. Am J Respir Cell Mol Biol. 2016;54(1):147-149. doi:10.1165/rcmb.2015-0147LE

304. Ioannidis N, Kurz B, Hansen U, Schunke M. Influence of fulvic acid on the collagen secretion of bovine chondrocytes in vitro. Cell Tissue Res. 1999;297(1):141-147. doi:10.1007/ s004410051341

305. Goto M, Suematsu Y, Nunes ACF, et al. Ferric citrate attenuates cardiac hypertrophy and fibrosis in a rat model of chronic kidney disease. Iran J Kidney Dis. 2019;13(2):98-104.

306. Chua F, Gauldie J, Laurent GJ. Pulmonary fibrosis: searching for model answers. Am J Respir Cell Mol Biol. 2005;33(1):9-13. doi:10.1165/rcmb.2005-0062TR

307. Kennedy JF, Tun HC. The degradation of hyaluronic acid by ferrous ions. Carbohydr Res. 1972;22(1):43-51. doi:10.1016 S0008-6215(00)85724-9

308. Merce AL, Marques Carrera LC, Santos Romanholi LK, Lobo Recio MA. Aqueous and solid complexes of iron(III) with hyaluronic acid. Potentiometric titrations and infrared spectroscopy studies. J Inorg Biochem. 2002;89(3-4):212-218. doi:10.1016/ S0162-0134(01)00422-6

309. Bracke KR, Dentener MA, Papakonstantinou E, et al. Enhanced deposition of low-molecular-weight hyaluronan in lungs of cigarette smoke-exposed mice. Am J Respir Cell Mol Biol. 2010;42 (6):753-761. doi:10.1165/rcmb.2008-0424OC
310. Matsumura G, Pigman W. Catalytic role of copper and iron ions in the depolymerization of hyaluronic acid by ascorbic acid. Arch Biochem Biophys. 1965;110(3):526-533. doi:10.1016/00039861(65)90446-7

311. Harris MJ, Herp A, Pigman W. Metal catalysis in the depolymerization of hyaluronic acid by autoxidants. $J$ Am Chem Soc. 1972;94(21):7570-7572. doi:10.1021/ja00776a047

312. Magalhaes MR, Da silva NJ Jr, Ulhoa CJ. A hyaluronidase from Potamotrygon motoro (freshwater stingrays) venom: isolation and characterization. Toxicon. 2008;51(6):1060-1067. doi:10.1016/j. toxicon.2008.01.008

313. Jiang D, Liang J, Noble PW. Regulation of non-infectious lung injury, inflammation, and repair by the extracellular matrix glycosaminoglycan hyaluronan. Anat Rec. 2010;293(6):982-985. doi:10.1002/ar.21102

314. Ghosh S, Hoselton SA, Dorsam GP, Schuh JM. Hyaluronan fragments as mediators of inflammation in allergic pulmonary disease. Immunobiology. 2015;220(5):575-588. doi:10.1016/j. imbio.2014.12.005

315. Müller S, Sindikubwabo F, Cañeque T, et al. CD44 regulates epigenetic plasticity by mediating iron endocytosis. Nat Chem. 2020;12(10):929-938. doi:10.1038/s41557-020-0513-5

316. Adesina AM, Vallyathan V, McQuillen EN, Weaver SO, Craighead JE. Bronchiolar inflammation and fibrosis associated with smoking. A morphologic cross-sectional population analysis. Am Rev Respir Dis. 1991;143(1):144-149. doi:10.1164/ajrccm/ 143.1 .144

317. Lang MR, Fiaux GW, Gillooly M, Stewart JA, Hulmes DJ, Lamb D. Collagen content of alveolar wall tissue in emphysematous and non-emphysematous lungs. Thorax. 1994;49 (4):319-326. doi:10.1136/thx.49.4.319

318. Wang RD, Wright JL, Churg A. Transforming growth factor-beta1 drives airway remodeling in cigarette smoke-exposed tracheal explants. Am J Respir Cell Mol Biol. 2005;33(4):387-393. doi:10.1165/rcmb.2005-0203OC

319. Bracke KR, D'Hulst AI, Maes T, et al. Cigarette smoke-induced pulmonary inflammation and emphysema are attenuated in CCR6-deficient mice. J Immunol. 2006;177(7):4350-4359. doi:10.4049/jimmunol.177.7.4350

320. Churg A, Tai H, Coulthard T, Wang R, Wright JL. Cigarette smoke drives small airway remodeling by induction of growth factors in the airway wall. Am J Respir Crit Care Med. 2006;174 (12):1327-1334. doi:10.1164/rccm.200605-585OC

321. Bracke KR, D'Hulst AI, Maes T, et al. Cigarette smoke-induced pulmonary inflammation, but not airway remodelling, is attenuated in chemokine receptor 5-deficient mice. Clin Exp Allergy. 2007;37(10):1467-1479. doi:10.1111/j.1365-2222.2007.02808.x

322. Churg A, Wang R, Wang X, Onnervik PO, Thim K, Wright JL. Effect of an MMP-9/MMP-12 inhibitor on smoke-induced emphysema and airway remodelling in Guinea pigs. Thorax. 2007;62(8):706-713. doi:10.1136/thx.2006.068353

323. Wright JL, Postma DS, Kerstjens HA, Timens W, Whittaker P, Churg A. Airway remodeling in the smoke exposed Guinea pig model. Inhal Toxicol. 2007;19(11):915-923. doi:10.1080/ 08958370701515563

324. Rosmus J, Vancikova O, Marc J, Deyl Z. Studies on the structure of collagen $\mathrm{V}$. The site of binding of trivalent iron on collagen. Experientia. 1967;23(11):898. doi:10.1007/BF02136206

325. Nakatani S, Naito I, Momota R, et al. In situ preparation of colloidal iron by microwave irradiation for transmission electron microscopy. Acta Med Okayama. 2006;60(1):59-64. doi:10.18926/AMO/30753

326. Tang R, Liao XP, Liu X, Shi B. Collagen fiber immobilized $\mathrm{Fe}(\mathrm{III})$ : a novel catalyst for photo-assisted degradation of dyes. Chem Commun. 2005;(47):5882-5884. doi:10.1039/b512184a 
327. Kinberger GA, Taulane JP, Goodman M. Fe(III)-binding collagen mimetics. Inorg Chem. 2006;45(3):961-963. doi:10.1021/ ic0520059

328. Huang CY, Wu CH, Yang JI, Li YH, Kuo JM. Evaluation of iron-binding activity of collagen peptides prepared from the scales of four cultivated fishes in Taiwan. J Food Drug Anal. 2015;23(4):671-678. doi:10.1016/j.jfda.2014.06.009

329. Kanagy JR, Kronstadt RA. Iron as a tanning agent. J Res Natl Bur Stand. 1943;31:279-292. doi:10.6028/jres.031.017

330. Fathima NN, Rao JR, Nair BU. Effect of UV irradiation on the physico-chemical properties of iron crosslinked collagen. J Photochem Photobiol B. 2011;105(3):203-206. doi:10.1016/j. jphotobiol.2011.09.003

331. Ikeda $\mathrm{H}, \mathrm{Wu} \mathrm{GY}, \mathrm{Wu} \mathrm{CH}$. Evidence that an iron chelator regulates collagen synthesis by decreasing the stability of procollagen mRNA. Hepatology. 1992;15(2):282-287. doi:10.1002/ hep. 1840150218

332. Gardi C, Arezzini B, Fortino V, Comporti M. Effect of free iron on collagen synthesis, cell proliferation and MMP-2 expression in rat hepatic stellate cells. Biochem Pharmacol. 2002;64 (7):1139-1145. doi:10.1016/S0006-2952(02)01257-1

333. Zhu C, Yang F, Fan D, Wang Y, Yu Y. Higher iron bioavailability of a human-like collagen iron complex. J Biomater Appl. 2017;32 (1):82-92. doi:10.1177/0885328217708638

334. Bunda S, Kaviani N, Hinek A. Fluctuations of intracellular iron modulate elastin production. J Biol Chem. 2005;280 (3):2341-2351. doi:10.1074/jbc.M409897200

335. Pieraggi M, Nejjar I, Julian M, Bouissou H. Staining of elastic tissue by Verhoeff's iron hematoxylin. Ann Pathol. 1986;6 (1):74-77.

336. Tilson MD. Histochemistry of aortic elastin in patients with nonspecific abdominal aortic aneurysmal disease. Arch Surg. 1988;123(4):503-505. doi:10.1001/ archsurg.1988.01400280113023

337. Piubelli MLM, Clemente LC, Duarte-Neto AN. Gamna-Gandy bodies of the spleen in sickle cell disease. Autops Case Rep. 2019;9(2):e2018076. doi:10.4322/acr.2018.076

338. Leopold JG, Gough J. The centrilobular form of hypertrophic emphysema and its relation to chronic bronchitis. Thorax. 1957;12(3):219-235. doi:10.1136/thx.12.3.219

339. Oderr CP. Emphysema, soot, and pulmonary circulation-macroscopic studies of aging lungs. $J$ Am Med Assoc. 1960;172:1991-1998. doi:10.1001/jama.1960.03020180001001

340. Pratt PC, Jutabha P, Klugh GA. The relationship between pigment deposits and lesions in normal and centrilobular emphysematous lungs. Am Rev Respir Dis. 1963;87:245-256. doi:10.1164/ arrd.1963.87.2.245

341. Pratt PC, Kilburn KH. A modern concept of the emphysemas based on correlations of structure and function. Hum Pathol. 1970;1(3):443-463. doi:10.1016/S0046-8177(70)80077-6

342. McLaughlin RF, Tueller EE. Anatomic and histologic changes of early emphysema. Chest. 1971;59(6):592-599. doi:10.1378/ chest.59.6.592

343. Churg A, Brauer M. Human lung parenchyma retains PM2.5. Am J Respir Crit Care Med. 1997;155(6):2109-2111. doi:10.1164/ ajrccm.155.6.9196123

344. Baibergenova A, Thabane L, Akhtar-Danesh N, Levine M, Gafni A, Leeb K. Sex differences in hospital admissions from emergency departments in asthmatic adults: a population-based study. Ann Allergy Asthma Immunol. 2006;96(5):666-672. doi:10.1016/S1081-1206(10)61063-0

345. McLean KH. The histology of generalized pulmonary emphysema. I. The genesis of the early centrolobular lesion: focal emphysema. Australas Ann Med. 1957;6(2):124-140. doi:10.1111/imj.1957.6.2.124
346. Sato K, Inoue S, Igarashi A, et al. Effect of iron deficiency on a murine model of smoke-induced emphysema. Am J Respir Cell Mol Biol. 2020;62(5):588-597. doi:10.1165/rcmb.2018-0239OC

347. Bledsoe G, Shen B, Yao Y, Zhang JJ, Chao L, Chao J. Reversal of renal fibrosis, inflammation, and glomerular hypertrophy by kallikrein gene delivery. Hum Gene Ther. 2006;17(5):545-555. doi:10.1089/hum.2006.17.545

348. Apte M, Pirola R, Wilson J. The fibrosis of chronic pancreatitis: new insights into the role of pancreatic stellate cells. Antioxid Redox Signal. 2011;15(10):2711-2722. doi:10.1089/ars.20 11.4079

349. Calvaruso V, Craxi A. Regression of fibrosis after HBV antiviral therapy. Is cirrhosis reversible? Liver Int. 2014;34(Suppl 1):85-90. doi:10.1111/liv.12395

350. Kong P, Christia P, Frangogiannis NG. The pathogenesis of cardiac fibrosis. Cell Mol Life Sci. 2014;71(4):549-574.

351. Manne V, Akhtar E, Saab S. Cirrhosis regression in patients with viral hepatitis B and C: a systematic review. J Clin Gastroenterol. 2014;48(9):e76-e84. doi:10.1097/MCG.0000000000000162

352. Ryerson CJ, Olsen SR, Carlsten C, et al. Fibrosing bronchiolitis evolving from infectious or inhalational acute bronchiolitis. A reversible lesion. Ann Am Thorac Soc. 2015;12 (9):1323-1327. doi:10.1513/AnnalsATS.201504-234BC

353. Fukuchi $\mathrm{K}$, Tomoyasu $\mathrm{S}$, Tsuruoka $\mathrm{N}$, Gomi $\mathrm{K}$. Iron deprivation-induced apoptosis in HL-60 cells. FEBS Lett. 1994;350(1):139-142. doi:10.1016/0014-5793(94)00755-1

354. Demedts IK, Demoor T, Bracke KR, Joos GF, Brusselle GG. Role of apoptosis in the pathogenesis of COPD and pulmonary emphysema. Respir Res. 2006;7:53.

355. Kasahara Y, Tuder RM, Taraseviciene-Stewart L, et al. Inhibition of VEGF receptors causes lung cell apoptosis and emphysema. J Clin Invest. 2000;106(11):1311-1319. doi:10.1172/JCI10259

356. Yokohori N, Aoshiba K, Nagai A; Respiratory Failure Research Group in Japan. Increased levels of cell death and proliferation in alveolar wall cells in patients with pulmonary emphysema. Chest. 2004; 125(2):626-632.

357. Calabrese F, Giacometti C, Beghe B, et al. Marked alveolar apoptosis/proliferation imbalance in end-stage emphysema. Respir Res. 2005;6:14. doi:10.1186/1465-9921-6-14

358. Imai K, Mercer BA, Schulman LL, Sonett JR, D’Armiento JM. Correlation of lung surface area to apoptosis and proliferation in human emphysema. Eur Respir J. 2005;25(2):250-258. doi:10.1183/09031936.05.00023704

359. Sharafkhaneh A, Hanania NA, Kim V. Pathogenesis of emphysema: from the bench to the bedside. Proc Am Thorac Soc. 2008;5 (4):475-477. doi:10.1513/pats.200708-126ET

360. Morissette MC, Parent J, Milot J. Alveolar epithelial and endothelial cell apoptosis in emphysema: what we know and what we need to know. Int J Chron Obstruct Pulmon Dis. 2009;4:19-31.

361. Mouded M, Egea EE, Brown MJ, et al. Epithelial cell apoptosis causes acute lung injury masquerading as emphysema. Am $J$ Respir Cell Mol Biol. 2009;41(4):407-414. doi:10.1165/ rcmb.2008-01370C

362. Podowski M, Calvi CL, Cheadle C, Tuder RM, Biswals S, Neptune ER. Complex integration of matrix, oxidative stress, and apoptosis in genetic emphysema. Am J Pathol. 2009;175 (1):84-96. doi:10.2353/ajpath.2009.080870

363. Farkas L, Farkas D, Warburton D, et al. Cigarette smoke exposure aggravates air space enlargement and alveolar cell apoptosis in Smad3 knockout mice. Am J Physiol Lung Cell Mol Physiol. 2011;301(4):L391-401. doi:10.1152/ajplung.00369.2010

364. Ruwanpura SM, McLeod L, Miller A, et al. Interleukin-6 promotes pulmonary emphysema associated with apoptosis in mice. Am J Respir Cell Mol Biol. 2011;45(4):720-730. doi:10.1165/ rcmb.2010-0462OC 
365. Shigeta A, Tada Y, Wang JY, et al. CD40 amplifies Fas-mediated apoptosis: a mechanism contributing to emphysema. Am J Physiol Lung Cell Mol Physiol. 2012;303(2):L141-51. doi:10.1152/ ajplung.00337.2011

366. Mimae T, Hagiyama M, Inoue $T$, et al. Increased ectodomain shedding of lung epithelial cell adhesion molecule 1 as a cause of increased alveolar cell apoptosis in emphysema. Thorax. 2014;69(3):223-231. doi:10.1136/thoraxjnl-2013-203867

367. Hou HH, Cheng SL, Chung KP, et al. PlGF mediates neutrophil elastase-induced airway epithelial cell apoptosis and emphysema. Respir Res. 2014;15:106. doi:10.1186/s12931-014-0106-1

368. Bodas M, Min T, Vij N. Lactosylceramide-accumulation in lipid-rafts mediate aberrant-autophagy, inflammation and apoptosis in cigarette smoke induced emphysema. Apoptosis. 2015;20 (5):725-739. doi:10.1007/s10495-015-1098-0

369. Gu C, Li Y, Xu WL, et al. Sirtuin 1 activator SRT1720 protects against lung injury via reduction of type II alveolar epithelial cells apoptosis in emphysema. COPD. 2015;12(4):444-452. doi: 10.3109/15412555.2014.974740

370. Hagiyama M, Yoneshige A, Inoue $T$, et al. The intracellular domain of cell adhesion molecule 1 is present in emphysematous lungs and induces lung epithelial cell apoptosis. J Biomed Sci. 2015;22:67. doi:10.1186/s12929-015-0173-8

371. Cecchi R, Spota A, Frati P, Muciaccia B. Migrating granulomatous chronic reaction from hyaluronic acid skin filler (Restylane): review and histopathological study with histochemical stainings. Dermatology. 2014;228(1):14-17. doi:10.1159/000356421

372. Caldas Pozuelo C, Dominguez De Dios J, Mota Rojas X. Multiple oral granulomatous nodules to hyaluronic acid filler. $J$ Cosmet Dermatol. 2020;19(12):3453-3455. doi:10.1111/jocd.13734

373. Desai SR, Wells AU, Rubens MB, Du Bois RM, Hansell DM. Traction bronchiectasis in cryptogenic fibrosing alveolitis: associated computed tomographic features and physiological significance. Eur Radiol. 2003;13(8):1801-1808.

374. Subramaniam RP, Asgharian B, Freijer JI, Miller FJ, Anjilvel S. Analysis of lobar differences in particle deposition in the human lung. Inhal Toxicol. 2003;15(1):1-21. doi:10.1080/08958 370304451

375. Thompson RW, Liao S, Curci JA. Vascular smooth muscle cell apoptosis in abdominal aortic aneurysms. Coron Artery Dis 1997;8(10):623-631. doi:10.1097/00019501-199710000-00005

376. Pentimalli L, Modesti A, Vignati A, et al. Role of apoptosis in intracranial aneurysm rupture. $J$ Neurosurg. 2004;101 (6):1018-1025. doi:10.3171/jns.2004.101.6.1018

377. Jacob T, Hingorani A, Ascher E. Role of apoptosis and proteolysis in the pathogenesis of iliac artery aneurysms. Vascular. 2005;13(1):34-42. doi:10.1258/rsmvasc.13.1.34

378. Topcu SO, Celik S, Erturhan S, Erbagci A, Yagci F, Ucak R. Verapamil prevents the apoptotic and hemodynamic changes in response to unilateral ureteral obstruction. Int $J$ Urol. 2008;15 (4):350-355. doi:10.1111/j.1442-2042.2008.01992.x

379. Dou S, Zheng C, Cui L, et al. High prevalence of bronchiectasis in emphysema-predominant COPD patients. Int J Chron Obstruct Pulmon Dis. 2018;13:2041-2047. doi:10.2147/COPD.S163243

380. Staats P, Kligerman S, Todd N, Tavora F, Xu L, Burke A. A comparative study of honeycombing on high resolution computed tomography with histologic lung remodeling in explants with usual interstitial pneumonia. Pathol Res Pract. 2015;211 (1):55-61. doi:10.1016/j.prp.2014.08.013

381. Piciucchi S, Tomassetti S, Ravaglia C, et al. From "traction bronchiectasis" to honeycombing in idiopathic pulmonary fibrosis: a spectrum of bronchiolar remodeling also in radiology? $B M C$ Pulm Med. 2016;16(1):87. doi:10.1186/s12890-016-0245-x

382. Hayes D Jr. Idiopathic pulmonary arterial hypertension misdiagnosed as asthma. J Asthma. 2007;44(1):19-22. doi:10.1080/ 02770900601125243
383. Achouh L, Montani D, Garcia G, et al. Pulmonary arterial hypertension masquerading as severe refractory asthma. Eur Respir J. 2008;32(2):513-516. doi:10.1183/09031936.00005408

384. Allen-Ramey FC, Gupta S, DiBonaventura MD. Patient characteristics, treatment patterns, and health outcomes among COPD phenotypes. Int J Chron Obstruct Pulmon Dis. 2012;7:779-787. doi:10.2147/COPD.S35501

385. Ashley F, Kannel WB, Sorlie PD, Masson R. Pulmonary function: relation to aging, cigarette habit, and mortality. Ann Intern Med. 1975;82(6):739-745. doi:10.7326/0003-4819-82-6-739

386. Kerstjens HA, Rijcken B, Schouten JP, Postma DS. Decline of FEV1 by age and smoking status: facts, figures, and fallacies. Thorax. 1997;52(9):820-827. doi:10.1136/thx.52.9.820

387. McKeever TM, Lewis SA, Smit HA, Burney P, Cassano PA, Britton J. A multivariate analysis of serum nutrient levels and lung function. Respir Res. 2008;9:67. doi:10.1186/1465-99219-67

388. Shibata Y, Inoue S, Igarashi A, et al. Elevated serum iron is a potent biomarker for spirometric resistance to cigarette smoke among Japanese males: the Takahata study. PLoS One. 2013;8(9): e74020. doi:10.1371/journal.pone.0074020

389. Brigham EP, McCormack MC, Takemoto CM, Matsui EC. Iron status is associated with asthma and lung function in US women. PLoS One. 2015;10(2):e0117545.

390. Lee CH, Goag EK, Lee SH, et al. Association of serum ferritin levels with smoking and lung function in the Korean adult population: analysis of the fourth and fifth Korean National Health and Nutrition Examination Survey. Int J Chron Obstruct Pulmon Dis. 2016;11:3001-3006. doi:10.2147/COPD.S116982

391. Ghio AJ, Hilborn ED. Indices of iron homeostasis correlate with airway obstruction in an NHANES III cohort. Int $J$ Chron Obstruct Pulmon Dis. 2017;12:2075-2084. doi:10.2147/COPD. S138457

392. Chambellan A, Chailleux E, Similowski T, Group AO. Prognostic value of the hematocrit in patients with severe COPD receiving long-term oxygen therapy. Chest. 2005;128(3):1201-1208. doi:10.1378/chest.128.3.1201

393. Halpern MT, Zilberberg MD, Schmier JK, Lau EC, Shorr AF. Anemia, costs and mortality in chronic obstructive pulmonary disease. Cost Eff Resour Alloc. 2006;4:17. doi:10.1186/14787547-4-17

394. Kollert F, Tippelt A, Muller C, et al. Hemoglobin levels above anemia thresholds are maximally predictive for long-term survival in COPD with chronic respiratory failure. Respir Care. 2013;58(7):1204-1212. doi:10.4187/respcare.01961

395. Schneckenpointner R, Jorres RA, Meidenbauer N, Kollert F, Pfeifer M, Budweiser S. The clinical significance of anaemia and disturbed iron homeostasis in chronic respiratory failure. Int J Clin Pract. 2014;68(1):130-138. doi:10.1111/ijcp.12216

396. Martinez-Rivera C, Portillo K, Munoz-Ferrer A, et al. Anemia is a mortality predictor in hospitalized patients for COPD exacerbation. COPD. 2012;9(3):243-250. doi:10.3109/ 15412555.2011.647131

397. Barba R, de Casasola GG, Marco J, et al. Anemia in chronic obstructive pulmonary disease: a readmission prognosis factor. Curr Med Res Opin. 2012;28(4):617-622. doi:10.1185/ 03007995.2012.675318

398. Nguyen HQ, Chu L, Amy Liu IL, et al. Associations between physical activity and 30-day readmission risk in chronic obstructive pulmonary disease. Ann Am Thorac Soc. 2014;11 (5):695-705. doi:10.1513/AnnalsATS.201401-017OC

399. Copur AS, Fulambarker A, Molnar J, et al. Role of anemia in home oxygen therapy in chronic obstructive pulmonary disease patients. Am J Ther. 2015;22(5):361-366. doi:10.1097/ MJT.0b013e3182785f7c 
400. Schonhofer B, Bohrer H, Kohler D. Blood transfusion facilitating difficult weaning from the ventilator. Anaesthesia. 1998;53 (2):181-184. doi:10.1046/j.1365-2044.1998.00275.x

401. Zhang WZ, Oromendia C, Kikkers SA, et al. Increased airway iron parameters and risk for exacerbation in COPD: an analysis from SPIROMICS. Sci Rep. 2020;10(1):10562. doi:10.1038/ s41598-020-67047-w

402. DeMeo DL, Mariani T, Bhattacharya S, et al. Integration of genomic and genetic approaches implicates IREB2 as a COPD susceptibility gene. Am J Hum Genet. 2009;85(4):493-502. doi:10.1016/j.ajhg.2009.09.004

403. Chappell SL, Daly L, Lotya J, et al. The role of IREB2 and transforming growth factor beta-1 genetic variants in COPD: a replication case-control study. BMC Med Genet. 2011;12:24. doi:10.1186/1471-2350-12-24

404. Ding Y, Yang D, Xun X, et al. Association of genetic polymorphisms with chronic obstructive pulmonary disease in the Hainan population: a case-control study. Int J Chron Obstruct Pulmon Dis. 2015;10:7-13. doi:10.2147/COPD.S73042

405. Weinberg ED. Iron availability and infection. Biochim Biophys Acta. 2009;1790(7):600-605. doi:10.1016/j.bbagen.2008.07.002

406. Ramakrishnan G, Sen B, Johnson R. Paralogous outer membrane proteins mediate uptake of different forms of iron and synergistically govern virulence in Francisella tularensis tularensis. $J$ Biol Chem. 2012;287(30):25191-25202. doi:10.1074/jbc.M112.3 71856

407. Grayson ML, Newton-John H. Smoking and varicella pneumonia. $J$ Infect. 1988;16(3):312. doi:10.1016/S0163-4453(88)97892-9

408. Straus WL, Plouffe JF, File TM Jr, et al. Risk factors for domestic acquisition of legionnaires disease. Arch Intern Med. 1996;156 (15):1685-1692. doi:10.1001/archinte.1996.00440140115011
409. Olson PE, Earhart KC, Rossetti RJ, Newton JA, Wallace MR. Smoking and risk of cryptococcosis in patients with AIDS. JAMA. 1997;277(8):629-630. doi:10.1001/jama.1997.035 40320031029

410. Almirall J, Gonzalez CA, Balanzo X, Bolibar I. Proportion of community-acquired pneumonia cases attributable to tobacco smoking. Chest. 1999;116(2):375-379. doi:10.1378/chest.11 6.2.375

411. Farr BM, Bartlett CL, Wadsworth J, Miller DL; British Thoracic Society Pneumonia Study Group. Risk factors for community-acquired pneumonia diagnosed upon hospital admission. Respir Med. 2000;94(10):954-963. doi:10.1053/ rmed.2000.0865

412. Nuorti JP, Butler JC, Farley MM, et al.; Active Bacterial Core Surveillance Team. Cigarette smoking and invasive pneumococcal disease. $N$ Engl J Med. 2000;342(10):681-689. doi:10.1056/ NEJM200003093421002

413. Doebbeling BN, Wenzel RP. The epidemiology of Legionella pneumophila infections. Semin Respir Infect. 1987;2(4):206-221.

414. Pastor P, Medley F, Murphy TV. Invasive pneumococcal disease in Dallas County, Texas: results from population-based surveillance in 1995. Clin Infect Dis. 1998;26(3):590-595. doi:10.1086/ 514589

415. Klement E, Talkington DF, Wasserzug O, et al. Identification of risk factors for infection in an outbreak of Mycoplasma pneumoniae respiratory tract disease. Clin Infect Dis. 2006;43 (10):1239-1245. doi:10.1086/508458

416. Bensenor IM, Cook NR, Lee IM, et al. Active and passive smoking and risk of colds in women. Ann Epidemiol. 2001;11 (4):225-231. doi:10.1016/S1047-2797(00)00214-3

\section{Publish your work in this journal}

The International Journal of COPD is an international, peer-reviewed journal of therapeutics and pharmacology focusing on concise rapid reporting of clinical studies and reviews in COPD. Special focus is given to the pathophysiological processes underlying the disease, intervention programs, patient focused education, and self management protocols. This journal is indexed on PubMed Central, MedLine and CAS. The manuscript management system is completely online and includes a very quick and fair peer-review system, which is all easy to use. Visit http://www.dovepress.com/testimonials.php to read real quotes from published authors. 